\title{
POPULATION DYNAMICS OF FRAXINUS NIGRA IN RESPONSE TO FLOOD-LEVEL VARIATIONS, IN NORTHWESTERN QUEBEC
}

\author{
JACQUES TARDIF ${ }^{1}$ AND YVES BERGERON \\ Groupe de recherche en écologie forestière and Département des sciences biologiques, \\ Université du Québec à Montréal, C.P. 8888, Succursale Centre-Ville, \\ Montréal, Québec, Canada H3C 3P8
}

\begin{abstract}
Population dynamics of black ash (Fraxinus nigra) were investigated in five stands with different exposures to spring flooding at the southwestern limit of Québec's boreal forest. Fifty-four $100-\mathrm{m}^{2}$ plots were sampled along 25 transects laid out perpendicular to Lake Duparquet. In each plot, all black ash $>5 \mathrm{~cm}$ in diameter at breast height (dbh) were aged using dendrochronological methods. An age-height regression was used to calculate the age of those individuals $<5 \mathrm{~cm}$ in dbh. Stump sprouts had a significantly faster height and diameter growth rate than individuals established from sexual origin. Two stands in this study showed deficits in sexual recruitment. One stand, located on a deep organic layer, also showed recent colonization by F. nigra that may have started during the 1930s. This stand had the highest stem density, and sprouting was restricted to the younger age classes. Ordination analysis of dispersion indices characterizing the age distribution of $F$. nigra indicated a definite pattern toward higher sexual recruitment in plots and stands that were less exposed to flooding. In contrast, poor sexual recruitment was observed on more exposed sites. However, this situation was compensated for by abundant vegetative recruitment. Analysis of the periods of growth release and suppression of 153 trees revealed that $F$. nigra population dynamics are not regulated by major disturbance events. A general upward trend in radial growth and $F$. nigra expansion toward higher elevation sites observed since the end of the 19th century may be due to changes in Lake Duparquet's hydrological regime. Increases in the severity of flooding events may result in the decrease in seedling abundance observed in the more exposed stands. F. nigra populations were found to be resistant to long-term natural water fluctuations due to their ability to regenerate both by seeds and by sprouts.
\end{abstract}

Key words: black ash; boreal forest; dendrochronology; flood exposure, effects on black ash demography; Fraxinus nigra, Marsh.; Lake Duparquet (Quebec, Canada); population dynamics of black ash; radial growth, release and suppression; regeneration, sexual vs. vegetative.

\section{INTRODUCTION}

In recent years, natural disturbances (fires, insect outbreaks, windstorms, floods, etc.) have been recognized as a major driving force in forest dynamics (e.g., White 1979, Pickett 1980, Pickett and White 1985, White 1987). It has also been pointed out that following climatic warming associated with increasing levels of greenhouse gases one of the changes will be in natural disturbance regimes and this will in turn affect forest dynamics (Clark 1988, Overpeck et al. 1990, Zavel'skaya et al. 1993, Apps et al. 1995).

In eastern North America, historical climate analyses have reported an increase in both temperature (Folland et al. 1990, Jones and Briffa 1992) and precipitation (Bradley et al. 1987, Karl et al. 1993) since the end of the Little Ice Age. This period, which is in part char-

Manuscript received 10 December 1996; revised 24 November 1997; accepted 18 December 1997; final version received 6 February 1998.

${ }^{1}$ Present address: University of Winnipeg, Department of Biology, 515 Portage Avenue, Winnipeg, Manitoba, Canada R3B 2E9. acterized by colder-than-average temperatures, lasted from about 1450 to 1850 (Lamb 1982). At the southwestern limit of Quebec's boreal forest, proxy records have also provided evidence of climatic changes in the last century. A dendrochronological reconstruction of fire history showed a natural decrease in forest fire frequency since the end of the Little Ice Age (Bergeron 1991, Bergeron and Archambault 1993, Bergeron and Flannigan 1995). Furthermore, Tardif and Bergeron (1997b) presented dendrochronological evidence showing that both water levels at spring breakup and ice damage have increased in the past $150 \mathrm{yr}$ on lake Duparquet (Quebec, Canada). Ice scars collected from mature Thuja occidentalis L. trees growing at the lake's edge were more frequent and reached higher levels in this century than in the late part of the Little Ice Age. From this study, it was inferred that water levels during major ice-breakup floods may be $\sim 100 \mathrm{~cm}$ higher in this century compared to the late part of the Little Ice Age (Tardif and Bergeron 1997b).

This change in Lake Duparquet's flooding regime has important ecological implications for floodplain tree population dynamics. It also allows us to study the 


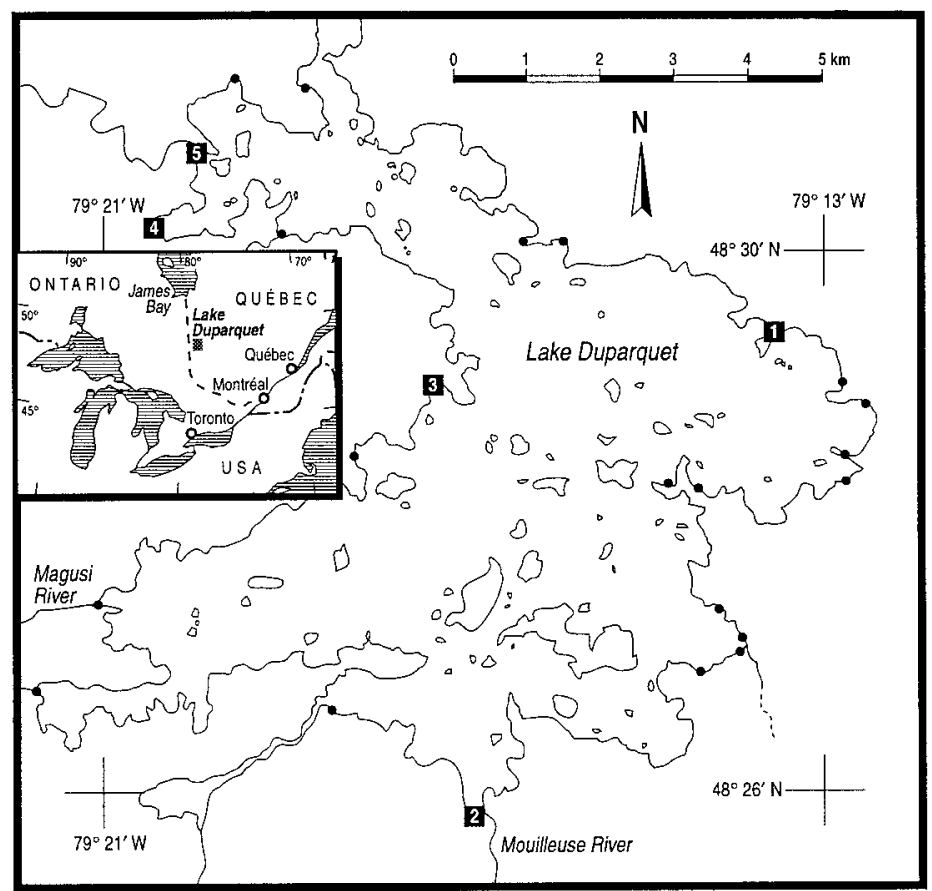

FIG. 1. Map of Lake Duparquet showing the distribution of Fraxinus nigra stands on the shore (solid circles) and locations of the five sampled stands: (1) on a sand bar, (2) beside a river, (3) in a bay with a bog, (4) far from any bog or river, and (5) on a river delta.

response of vegetation to both short- and long-term fluctuations in flooding. On floodplains, forest dynamics are mainly affected by flood frequency and magnitude (e.g., White 1979). Physical damage caused by floating ice and debris, as well as by erosion and deposition processes, is a major cause of tree mortality (Lindsey et al. 1961, Sigafoos 1964, Yanosky 1982, Barnes 1985). Flooding, however, also has beneficial effects and, in many tree species, germination is facilitated by seed immersion (Hosner 1957, DuBarry Jr. 1963). Seedling establishment may also benefit from better soil moisture conditions associated with floods of short duration (Hosner and Boyce 1962, McBride and Strahan 1984, Streng et al. 1989, Stromberg and Patten 1990, Johnson 1994).

In this study we examined the dynamics of black ash (Fraxinus nigra Marsh.) populations growing on Lake Duparquet's floodplains in relation to the effect of increasing flood levels. In eastern North America, black ash is a tree species typical of bogs and the edges of streams or poorly drained sites where there is a high water table and infrequent standing water (Sims et al. 1990, Wright and Rauscher 1990). In the Lake Duparquet area, $F$. nigra usually develops in pure stands along the shores of lakes and rivers (Tardif and Bergeron 1992). In our area, recent studies have indicated that flood duration was an important factor influencing stand dynamics. Understory vegetation distribution and $F$. nigra regeneration and radial growth responded to fluctuations in either flood timing, flood duration, or groundwater supply during the growing season (Tardif and Bergeron 1992, 1993, 1997a, Tardif et al. 1994, Tardif 1996). However, the demography of $F$. nigra
(Wright and Rauscher 1990, Tardif et al. 1994) and, in general, changes in the age-distribution patterns of long-lived plants, remains poorly understood (Harper 1977).

We hypothesized that, at the lake scale, populations of $F$. nigra are in dynamic equilibrium, whereas at a smaller scale the demographic characteristics of each subpopulation will not necessarily be in an equilibrium state but will instead reflect flood exposure and disturbances associated with the higher water levels of this century. The objective was, therefore, to document the spatial and temporal dynamics of $F$. nigra populations and to assess their resistance to increasing flood levels. Specifically, we (1) investigated how flooding interferes with $F$. nigra sexual and vegetative regeneration success in sites that are exposed to different degrees of flooding and (2) documented long-term growth trends and past disturbance events through an analysis of age distributions and radial growth patterns.

\section{Methods}

\section{Study area}

Lake Duparquet is a large, unregulated body of water located in the Abitibi region $\left(48^{\circ} 28^{\prime} \mathrm{N}, 79^{\circ} 17^{\prime} \mathrm{W}\right.$ ) of northwestern Quebec (Fig. 1). This region is part of the Northern Clay Belt of Quebec and Ontario that resulted from the maximum extension of proglacial Lakes Barlow and Ojibway (Veillette 1994). Lake Duparquet, with an area of $50 \mathrm{~km}^{2}$, is part of a vast watershed that drains northward from the Duparquet River to James Bay. The closest meteorological station is at La Sarre, $\sim 42 \mathrm{~km}$ to the north. The 1961-1990 mean 
TABLE 1. Descriptive sampling and ecological parameters for each of the five Fraxinus nigra study stands on Lake Duparquet (Quebec, Canada). Data for the ecological factors are means and $1 \mathrm{SD}$.

\begin{tabular}{lrrrrrrr}
\hline \hline & \multicolumn{7}{c}{ Stand number $\dagger$} \\
\cline { 2 - 8 } \multicolumn{1}{c}{ Parameters } & 1 & 5 & 2 & $3 \mathrm{a}$ & 4 & $3 \mathrm{~b}$ & $\begin{array}{c}\text { Entire } \\
\text { lake }\end{array}$ \\
\hline Number of transects & 3 & 5 & 6 & 3 & 5 & 3 & 25 \\
Number of 100-m ${ }^{2}$ plots & 6 & 10 & 12 & 8 & 9 & 9 & 54 \\
Ecological factors & & & & & & & \\
$\quad$ Average distance to the lake (m) & 28.6 & 71.8 & 62.5 & 55.6 & 33.5 & 63.3 & 54.8 \\
$\quad$ 1 SD & 14.7 & 8.1 & 24.6 & 31.0 & 11.1 & 28.9 & 25.8 \\
Average elevation above the lake (m) & 1.4 & 0.3 & 1.5 & 1.9 & 1.2 & 1.5 & 1.3 \\
$\quad$ 1 SD & 0.2 & 0.2 & 0.4 & 0.7 & 0.3 & 0.3 & 0.6 \\
Average slope (\%) & 2.1 & 0.6 & 2.0 & 1.6 & 4.0 & 1.2 & 1.9 \\
$\quad$ 1 SD & 2.2 & 0.4 & 1.2 & 0.9 & 2.6 & 0.5 & 1.8 \\
Average depth of organic matter (cm) & 21.7 & 8.3 & 12.6 & 16.3 & 24.8 & 70.4 & 25.0 \\
$\quad$ 1 SD & 26.3 & 2.6 & 12.4 & 14.2 & 23.8 & 17.6 & 26.6 \\
Average percentage clay & 23.8 & 43.6 & 30.0 & 29.4 & 21.6 & 6.5 & 26.4 \\
$\quad$ 1 SD & 7.6 & 2.9 & 13.2 & 13.2 & 13.9 & 8.2 & 15.4 \\
\hline
\end{tabular}

$\dagger$ Stands are presented, left to right, in order of expected decreasing exposure to flooding. $\$$ Composite information from the five stands around Lake Duparquet that were studied (i.e., Fig. 1: numbered squares).

annual temperature and total precipitation were, respectively, $0.8^{\circ} \mathrm{C}$ and $856.8 \mathrm{~mm}$ (Environment Canada 1993). Most of the precipitation falls during the growing season and snow represents $25 \%$ of the yearly precipitation. The mean frost-free period is $64 \mathrm{~d}$ but freezing temperatures can occur at any time of the year (Environment Canada 1993).

Lake Duparquet is at the southwestern limit of Quebec's boreal forest (Rowe 1972) where late successional stands are dominated by balsam fir (Abies balsamea L. Mill.) and white birch (Betula papyrifera Marsh.) (Bergeron and Bouchard 1984). In this area, Fraxinus nigra dominates on hydric sites with high water fluctuation (alluvial levees and floodplains). On better drained sites it is mixed with balsam fir and white birch (Bergeron et al. 1983). Around Lake Duparquet, most $F$. nigra stands are found on floodplains located at the mouths of rivers and streams (Fig. 1). In the spring, generally between early May and early June, these stands are flooded, due in part to snow melt and spring precipitation. Based on work by Tardif and Bergeron (1997b), it was calculated that flooding of the most exposed black ash stands, for the period from 1915 to 1991 , may be observed anytime between 7 April and 13 July. Flooding lasted on average $24 \pm 17$ $\mathrm{d}$, with a range from 0 to $65 \mathrm{~d}$. In this area, lakes usually freeze around mid-November and become free of ice, on average, between 20 April and 10 May (Allen 1964). Limited cutting has occurred in the area since the early 20 th century, and fires also occur on a cycle of $\sim 100$ yr, but neither disturbance has much affected the $F$. nigra stands around the lake (Bergeron 1991). The lake watershed was also protected from intensive forestry activities until the late 1970s (Harvey and Bergeron 1989).

\section{Stand selection}

A preliminary sampling of the $F$. nigra stands along the shore of Lake Duparquet allowed us to locate 20 stands (Fig. 1). Each stand was characterized by distinct geomorphological landforms: (1) on a sand bar, (2) beside a river, (3) in a bay with a bog, (4) far from any bog or river and (5) on a river delta. For each type, the largest stand showing the least amount of human disturbance was chosen to test our hypotheses (Fig. 1). In two situations (1 and 5), a few large-diameter trees were harvested for fuel wood in the late 1970s-early 1980s. In each selected stand, sampling was done using $10 \times 10 \mathrm{~m}^{2}$ plots distributed along transects perpendicular to the lake. In most cases, two to three $100-\mathrm{m}^{2}$ plots were sampled along each transect, for a total of 54 plots distributed along 25 transects (Table 1).

By their different geomorphical landform, each of the five selected stands reflects a different exposure to flooding and/or to disturbance associated with higher flood-water levels. Both stands 1 and 5 are expected to be the most prone to flood impacts. The plots in stand 5 are found at lower elevations than other plots (Table 1); however, their great distance to the lake may constitute a protection from direct physical damage. The plots from stand 1 are found at higher elevations but are closer to the lake. Located on a sand bar, stand 1 is exposed to dominant westerly winds and is believed to be more prone to wave and ice damage. Both stands 1 and 5 are also isolated, with few possibilities for trees to migrate in higher elevation sites.

In comparison, plots in stands 2 and 3 a occur along a definite gradient of exposure to flooding with distance (elevation) from the lake. This is illustrated by both their higher mean elevation and greater mean distance 
(and standard deviations) from the lake (Table 1). Stand 3 was subdivided into two parts ( $3 a$ and $3 b$ ) because of the different species composition and dynamics associated with the $100-\mathrm{m}^{2}$ plots (3b) located on the deep organic soils of this part of the stand (Tardif and Bergeron 1992). Plots in stand 4, located in a small protected bay, also occur along a gradient of exposure to flooding. In this stand the most distant plots are found on the steepest part of the slope (Table 1). Furthermore, since sampling was done using transects perpendicular to the lake, it is expected that the plots on each transect, irrespective of their geomorphological landform, will represent a gradient in flood magnitude and frequency. This design permits us to better understand the importance of environmental gradients in modifying $F$. nigra's dynamics, i.e., from disturbance-prone sites to particularly protected ones (White 1979).

\section{Data collection}

In each of the $100-\mathrm{m}^{2}$ plots, diameter at breast height (dbh) was measured for all $F$. nigra trees $>5 \mathrm{~cm} \mathrm{dbh}$. Saplings $<5 \mathrm{~cm}$ dbh were counted in $1-\mathrm{cm}$ dbh classes. The abundance of seedlings $<10 \mathrm{~cm}$ tall and of $1 \mathrm{st}-\mathrm{yr}$ seedlings, easily identifiable by their aboveground cotyledons (Erdmann et al. 1987), was assessed in three $1-\mathrm{m}^{2}$ quadrats distributed along a transect centered in each of the $100-\mathrm{m}^{2}$ plots. When seedlings were not found in the $1-\mathrm{m}^{2}$ quadrats, the $100-\mathrm{m}^{2}$ plot was surveyed and if present they were attributed a density of 1 .

The origin (sexual or vegetative) and the physiological state (live or dead) of all standing $F$. nigra were noted. In this study, stems originating from the base or at the root collar of each individual (live or dead) were recorded as sprouts. For clumped or isolated stems, evidence of the mother tree (rotten stumps, circular arrangement, crescent-shaped stem bases) was also used as a criterion for vegetative origin (e.g., Sigafoos 1964, Phipps 1970, Barnes 1985, Palik and Pregitzer 1992). Sprout abundance will, however, be underestimated by this method because those that originated from small stems no longer bear traces of the mother tree. Because of frequent heart rot, juvenile radial growth typical of sprouts could also not be used as a practical technique to further distinguish stem origin.

In each $100-\mathrm{m}^{2}$ plot, all live $F$. nigra trees $(>5 \mathrm{~cm}$ $\mathrm{dbh}$ ) were aged by taking increment cores as close as possible to ground level with a Swedish (HAGLOF, Landsale, Sweden) increment borer. When decayed areas or hollow centers were encountered, a core was taken higher on the trunk, and its height was recorded to permit later adjustments using an age-correction factor. The height of all individuals $<5 \mathrm{~cm}$ dbh was also measured to estimate their age from an age-height regression analysis. Accordingly, in each $100-\mathrm{m}^{2}$ plot, a cross section was taken as close as possible to the root collar (base of the tree) from a sub sample of specimens in each of the diameter classes for age determination. In each $100-\mathrm{m}^{2}$ plot or in its immediate periphery
( $<5 \mathrm{~m}$ ), the three largest $F$. nigra trees were also cored for radial-growth measurements. Two cores were taken from each of these trees $\sim 1.5 \mathrm{~m}$ above the ground (Tardif and Bergeron 1993). The height of these trees was also measured with a clinometer. Topographic position, edaphic characteristics, and composition of the vegetation were also measured in each $100-\mathrm{m}^{2}$ plot (Tardif and Bergeron 1992).

\section{Age determination}

All cores and cross sections were prepared following standard dendrochronological methods (Stokes and Smiley 1968). Ages were determined by tree-ring counts and crossdating under a binocular microscope. Crossdating was facilitated by the presence of numerous marker years (Tardif and Bergeron 1993). After crossdating, the growth increments of the three largest $F$. nigra trees sampled for ring-width analysis were also measured to $0.01 \mathrm{~mm}$ with a Henson micrometer. For seedlings and saplings crossdating was often difficult because of the suppressed ring widths and low numbers of rings, and age was determined by ring counts. These were counted 2-3 times by separate observers to reduce the risk of errors in ring counts.

The age of specimens $<5 \mathrm{~cm}$ dbh was estimated using separate height-age regression equations for both sprouts and stems from sexual origin (henceforth the latter, unless otherwise indicated, will be referred to as "seedlings"). For this regression analysis, data from an earlier study were also used (Tardif et al. 1994), but only individuals $<5 \mathrm{~cm}$ dbh were included in this analysis. The large proportion of the variance explained by these regressions [sprouts: $R^{2}=0.61, P<0.0001, n$ $=493$ sprouts, $\log _{10}(y)=0.8 \times \log _{10}(x)-0.68$, and seedlings: $R^{2}=0.87, P<0.0001, n=678$ seedlings, $\left.\log _{10}(y)=-0.38 \times \log _{10}\left(x^{2}\right)+2.24 \times \log _{10}(x)-1.56\right]$ justified their use in age determination. These regression equations were also used as a correction factor to adjust for the height of the core taken on trees from sexual origin (Hett and Loucks 1976, Bergeron and Gagnon 1987). The age of sprouts was, however, not corrected for core height because of their vigorous juvenile height growth (Erdmann et al. 1987). To further minimize the error resulting from age estimations, all age distributions were filtered using a 5-yr unweighted running average and are presented in 10-yr classes. Data were also transformed to the hectare to allow for comparisons between stands.

\section{Statistical analysis}

In this study, population dynamics were investigated by using both age and size frequency distributions and tree-ring width analyses. Three scales of analyses (lake, stand, and $100-\mathrm{m}^{2}$ ) were conducted using the age and size frequency distributions from the $54100-\mathrm{m}^{2}$ plots. At the lake and stand level, both age and size frequency distributions were calculated. In long-lived tree species, both static and cumulative age and size distri- 
butions have been used to infer populations dynamics (Henry and Swan 1974, Lorimer 1980, Ross et al. 1982, Knowles and Grant 1983, Parker and Peet 1984, Glitzenstein et al. 1986, Butson et al. 1987, Platt et al. 1988, Payette et al. 1990, Palik and Pregitzer 1992, Tyrell and Crow 1994). It is broadly accepted that stable populations present an inverted-"J"-shaped distribution characterized by a declining density with increasing age or size. Under the assumption of constant recruitment and mortality through time, both static and cumulative age distributions also approximate survivorship curves (coinciding slopes; Leak 1975), which indicate survival probability with time.

Both the negative exponential function (constant recruitment and constant mortality with age) and the power function (constant recruitment and decreasing mortality with age) models have been applied to describe tree populations, and departure from these models has often been used to infer past recruitment and/ or mortality events (Hett 1971, Leak 1975, Hett and Loucks 1976, Cawker 1980, Ågren and Zackrisson 1990, Baker 1990, Tardif et al. 1994). In this study, both static and cumulative age distributions were used to compare $F$. nigra (seedlings, sprouts, and pooled) population dynamics assuming a constant recruitment and mortality model. The pooled (sprouts and seedlings) cumulative distribution was used as a comparison because of potential problems with sprout identification. For each stand, a significant deviation between the slope of the static and the cumulative age distributions as indicated by a covariance analysis was used as an indicator of nonequilibrium conditions. To investigate between-stand differences, all cumulative age distributions were also submitted to a pairwise analysis of covariance. In each stand, the age-specific slope of the cumulative age curve is a measure of the age-specific probability of survival and indicates a loss from one age class to the other, whereas, the intercept indicates the initial recruitment. Departure from the model is also related to different mortality rates during the time span of the observation, assuming constant regeneration.

In this study, multivariate analyses were used to assess disparity between age frequency distributions at the lake, stand, and $100-\mathrm{m}^{2}$ plot scales. For each level of analysis, standard descriptive measures (total abundance, $n$; arithmetic mean, "me"; maximum age class, "mx"; medium age class, "md"; skewness, "sk"; and number of age classes present, "ri") were calculated to characterize the sprout (" $r$ ") and seedling ("s") age distributions. To explore the relationships between these descriptors at the lake and stand level, we used a principal-component analysis (PCA). To better understand the importance of environmental gradients in modulating $F$. nigra's dynamics at the $100-\mathrm{m}^{2}$ level, both PCA and redundancy analysis (RDA) were used. The latter has the advantage of emphasizing the relationship between descriptor and external factors (ter
Braak 1988). A forward selection of environmental factors was used and each variable was tested using 200 random Monte Carlo permutations. Elevation and distance to the lake, percentage slope, depth of organic matter, percentage clay, and stand geomorphological situation (dummy variables) were used as environmental factors. Because of the different units in which our descriptive measures are expressed, PCA and RDA were favored over correspondence analysis (Legendre and Legendre 1984). The PCA and RDA were conducted on a correlation matrix, and scaling of ordination scores was done using a correlation bi-plot. The CANOCO program (Version 3.1) was used (ter Braak 1988).

Both 1st-yr and $<10-\mathrm{cm}$ height seedlings were not included in these analyses because of the small number of $1-\mathrm{m}^{2}$ plots in which they were counted. Their conversion to the hectare without an assessment of their spatial distribution within the $100-\mathrm{m}^{2}$ plots may be fallacious, and these classes have thus been eliminated. Two plots from stand $3 \mathrm{~b}$ were also not included because of the near absence of $F$. nigra stems. SAS release 6.03 was used for these statistical analyses (SAS Institute 1988).

Finally, to highlight disturbance events that could have affected $F$. nigra stand dynamics, establishment years at the stand level were compared to radial growth patterns. This helps to assess whether initial stem recruitment was related to past disturbance events (Orwig and Abrams 1994). In this analysis, the recruitment dates of all trees $(>5 \mathrm{~cm} \mathrm{dbh})$ were included whereas for saplings ( $<5 \mathrm{~cm} \mathrm{dbh})$, only those that were not ageestimated were used (see Figs. 8A-13A). To highlight both disturbance events and low-frequency trends in radial growth, the ring-width series (two cores) from the three largest F. nigra sampled in each of the 100$\mathrm{m}^{2}$ plots were analyzed.

Sustained radial growth release and suppression were identified in accordance with criteria developed by Glitzenstein et al. (1986). A significant growth release was recorded when ring width in suppressed trees $(<0.50 \mathrm{~mm} / \mathrm{yr})$ at least doubled over a $3-\mathrm{yr}$ period and this increase was maintained for $10 \mathrm{yr}$ or more when compared with the 10 preceding years. In non-suppressed trees $(>0.50 \mathrm{~mm} / \mathrm{yr})$, ring width had to increase by more than $50 \%$ over a 3 -yr period, and this increase, as for suppressed trees, had to be maintained for the next 10 yr. Suppression periods were identified using the same criteria except that a sharp decrease in growth was defined as a $50 \%$ growth reduction for non-suppressed trees and as a $25 \%$ reduction for suppressed trees. In addition, we calculated the frequency of cores showing at least a $75 \%$ release or suppression in growth using a less conservative approach. A period of suppression started when radial growth showed a $75 \%$ reduction for at least 10 consecutive years when compared to the 10 preceding years (ratio $<0.75$ ) and release from suppression was defined as a $75 \%$ or more 
gain in growth for 10 consecutive years when compared to the 10 preceding years (ratio $>1.75$ ).

To highlight low-frequency trends, an index chronology was computed for each stand following standardization of the ring-width series using the program CRONOL from the Dendrochronology Program Library (Holmes 1992). All stand chronologies were computed using a biweight robust mean to enhance the common signal contained in the data and to diminish the effect of possible outliers. Standardization of each series was done using an iterative approach (option 2 in program CRONOL). First a negative exponential curve was fitted to the data, and if it failed a linear regression of negative slope or a straight line through the mean was fitted. This method of detrending was favored over the use of more flexible cubic splines, which are believed to remove long-term upward growth trends not related to tree aging. Before standardization and to further ensure that our chronologies were not biased, all series were examined visually and the first years of growth were deleted if they showed a period of either abnormally strong or low growth in those years. This situation was, however, rarely observed. In addition, $F$. nigra seldom approached an age-related growth curve of the negative exponential type usually typical of shade-intolerant species. The straight-line detrending was thus selected for $64 \%$ of the cores by CRONOL. Straight-line standardization gives an equal weight to slow- and fast-growing trees without altering each series' low-frequency trends (Fritts 1976).

\section{RESUlts}

\section{Sprout and seedling age-size relationships}

Height-growth regressions using stems both $>5 \mathrm{~cm}$ and $<5 \mathrm{~cm} \mathrm{dbh}$ were found to differ significantly according to stem origin. For sprouts, the age-height relationship was best fitted by a first-order regression, whereas seedlings were best fitted by a second-order polynomial regression (Fig. 2A, B). Similar results were also obtained using only specimens $<5 \mathrm{~cm}$ dbh (see Methods: Age determination). In both cases, height was a better predictor of seedling age than of sprout age as indicated by the higher $R^{2}(0.88$ and 0.67 , respectively). Stem diameter was also a good predictor of sprout and seedling age (Fig. 2C, D). Sprout diameter was a better predictor of age than was stem height. For both origins, diameter was significantly correlated to stem height (Fig. 2E, F).

For these analyses, regression coefficients were highly significant and both seedling and sprout regressions had significantly different intercepts and slopes (ANCOVA, $P<0.0001$; Fig. $2 \mathrm{~A}-\mathrm{D}$ ). At any given height or diameter, sprouts were statistically younger than seedlings. At any given diameter, sprouts were also significantly taller than seedlings (ANCOVA, $P<$ 0.0001; Fig. 2E, F).
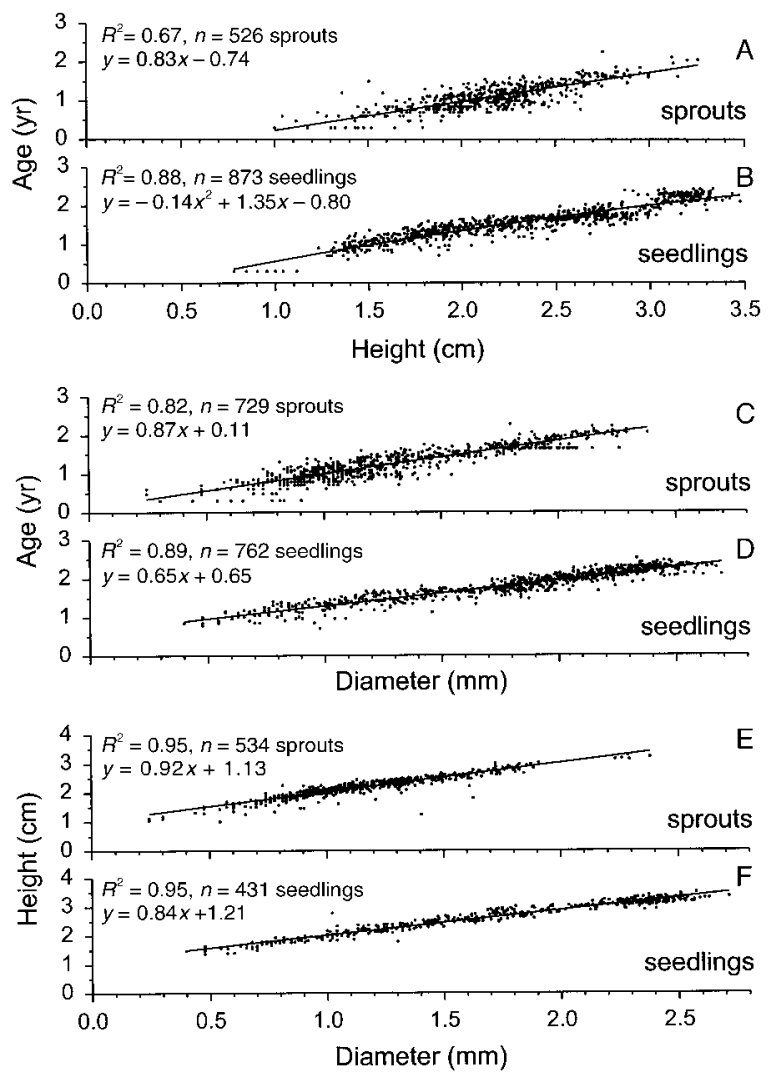

FIG. 2. Age-height (a, b), age-diameter (c, d), and height-diameter (e, f) regressions for Fraxinus nigra stems $<5 \mathrm{~cm}$ and $>5 \mathrm{~cm}$ in diameter at breast height (dbh). All data were converted using a $\log _{10}$ transformation. Sprouts (A, $\mathrm{C}$, and $\mathrm{E}$ ) and seedlings (B, D, and F) were analyzed separately. For all stems $<5 \mathrm{~cm}$ dbh, a cross-section diameter was used instead of $1-\mathrm{cm}$ dbh classes.

\section{Lake composite static and cumulative age distributions}

The lake (or composite) F. nigra age and diameter distributions approach states of equilibrium as shown by the repartition of individuals in all age classes (Fig. 3 ). A continuous recruitment of individuals was observed since 1710. Cumulative age distributions (seedlings, sprouts, and pooled) also approximate a constant mortality model as shown by an $R^{2}$ close to 0.98 (Table 2). A break in the distribution was, however, observed in $\sim 1930$ s-1940s. Seedling mortality as indicated by the cumulative distribution seemed to be highest in the very first age classes, levelled off in the middle age classes and rose again as trees approach $200 \mathrm{yr}$ of age (Fig. 3A). In contrast, F. nigra sprouts have higher mortality rates than seedlings. Both the seedlings and the pooled cumulative age distributions were also not found to be statistically different, indicating the limited importance of sprouts in the lake age distribution (Table 2 ). Sprouts were, however, more abundant than seedlings in the youngest age classes (Fig. 3). A continuous 

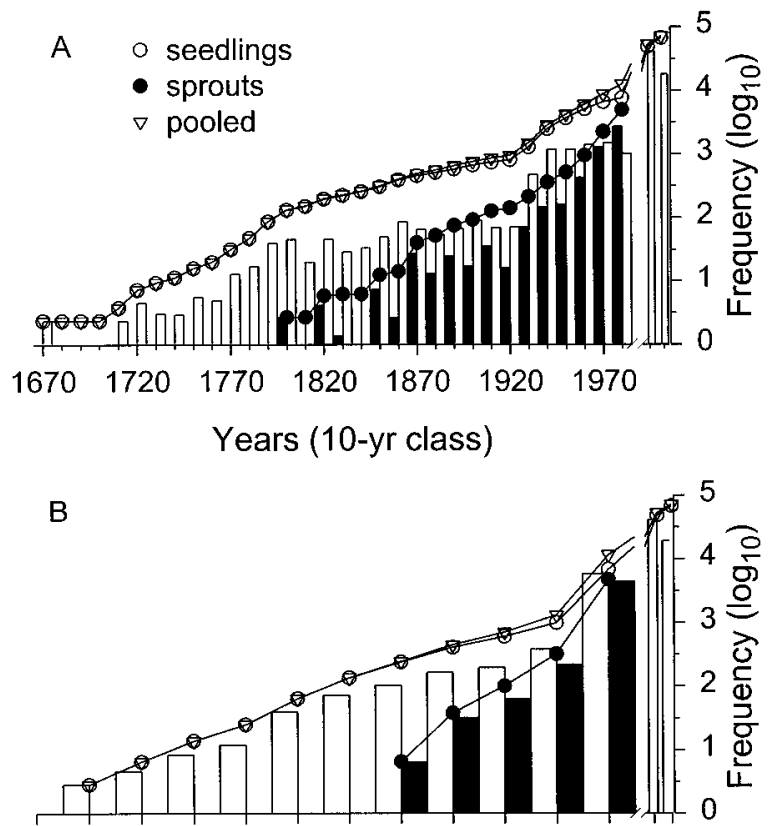

$60 \quad 55 \quad 50 \quad 45 \quad 40 \quad 35 \quad 30 \quad 25 \quad 20 \quad 15 \quad 10 \quad 5$

\section{Diameter (5-cm class)}

FIG. 3. Lake Duparquet $\log _{10}$-transformed composite (a) age and (b) diameter distributions for Fraxinus nigra stems from sexual and vegetative origins. Solid bars = sprouts; empty bars $=$ seedlings. The lines represent the corresponding cumulative distributions, and the pooled seedling-sprout cumulative age distribution is also indicated. Post-break data in each plot include, respectively, $<10-\mathrm{cm}$ height and firstyear seedlings.

recruitment from sprouts was observed starting in about 1850 .

\section{Stand age and diameter distributions}

Figs. 4 and 5, respectively, illustrate the $F$. nigra age and diameter distributions for each of the five sampled stands. Unless otherwise mentioned, only results from the age distributions are presented because of the similarity between the age and size distributions. The presentation of the stands follows (top to bottom of the page) an expected gradient of exposure, that is from stands more exposed to less exposed to flooding. As a general result, it can be observed in all stands that stems from sexual origin reach an older age and a larger diameter than do those from sprouts (Figs. 4, 5).

In stands more exposed to flooding ( 1 and 5), sprouts were distributed in a greater number of age classes and attain some of the oldest ages found (Fig. 4A, B). In these stands, sprouts were dominant in the younger age classes, and dominance compared to seedlings was emphasized by the departure of the pooled cumulative age curve from the seedling curve at the turn of the century. This is further emphasized in stand 1 by the statistically different intercept and slope of the seedlings and pooled cumulative distributions, whereas only the in- tercept approached a statistical difference in stand 5 (Table 2). Despite the low abundance of seedlings in these stands, trees from sexual origin are, however, observed in continuous age classes (Fig. 4A, B). The lowest abundance of first-year and $<10 \mathrm{~cm}$ tall seedlings was recorded in stand 1 (Fig. 4A). In contrast, the largest abundance of first-year seedlings was registered in stand 5 (Fig. 4B). In both stands, survival after germination is, however, extremely low as suggested by the low densities of $<10 \mathrm{~cm}$ tall and older (up to $\sim 70$ yrs of age) seedlings (Figs. 4 and $5 \mathrm{~A}, \mathrm{~B}$ ).

In contrast, age distributions in stands less exposed to flooding ( $3 \mathrm{~b}$ and 4 ) were characterized by abundant seedlings in the younger age classes (Fig. 4E, F). In both of these stands, stems from sexual origin up to $10-\mathrm{cm}$ dbh were the most abundant (Fig. 5E, F). Sprouts also have a small effect on the overall age distribution (Table 2, Fig. 4E, F). However, it should be noted that the age distribution in both stands differs. In stand 4, older trees were observed in continuous age classes (Fig. 4E). Of all the stands, stand $3 \mathrm{~b}$ was the furthest from being well balanced, with a sharp rise in seedling density occurring in the 1930s (Fig. 4F). This stand had the greatest recorded density of seedlings, up to the $10-\mathrm{cm}$ dbh class, when compared to the other stands (Fig. 5). Recruitment from seedlings also occurred in three distinct periods (approximately 1800-1860, 1860-1930, and 1930-1989) as indicated by changes in the slope of the cumulative age distribution (Fig. $4 \mathrm{~F}$ ). Two sprout cohorts were found in the age distribution and no sprouts were observed from about 1900 to 1940 (Fig. 4F).

Between these extremes, stands 2 and 3a occupy an intermediate position and include the oldest $F$. nigra in the study (Fig. 4C, D). In these stands, first-year and $<10$-cm-tall seedlings attain their greatest numbers, with stand 3 a having the highest recorded density. The contribution of sprouts to the overall age distribution was lower than in stands 1 and 5 and was mainly observed after the 1960 s. Sprouts were also mainly restricted to the $0-5 \mathrm{~cm}$ dbh class (Fig. 5C, D).

\section{Cumulative stand-age distributions}

The cumulative age distributions for F. nigra (seedlings, sprouts, and pooled) showed that most stands approximate a negative exponential distribution with a near constant mortality through time (Fig. 4, Table 2). Stand comparisons show that in stand $3 \mathrm{~b}$ seedlings have a significantly higher initial recruitment and mortality rate than in the other stands (Table 2). In stand 4, both were also significantly higher than in stands 1,2 , and 3a, whereas only mortality was significantly higher than in stand 5. Seedling mortality and initial recruitment were also similar in stands 1, 2, 3a, and 5. For stands 1 and 5, however, the regressions had lower $R^{2}$. For these stands, both the static and the cumulative age distributions of seedlings also had significantly different slopes (Table 2). Furthermore, the cumulative age 
TABLE 2. Results of ANCOVA for each of the seedling, sprout, and pooled cumulative age distributions of Fraxinus nigra presented in Fig. 5.

\begin{tabular}{|c|c|c|c|c|c|c|c|}
\hline \multirow[b]{2}{*}{ Statistic } & \multicolumn{6}{|c|}{ Stand number } & \multirow{2}{*}{$\begin{array}{c}\text { Entire } \\
\text { lake }\end{array}$} \\
\hline & 1 & 5 & 2 & $3 a$ & 4 & $3 \mathrm{~b}$ & \\
\hline \multicolumn{8}{|l|}{ Seedlings } \\
\hline$n$ & 20 & 25 & 33 & 27 & 20 & 19 & 33 \\
\hline$R^{2}$ & $0.872 \dagger$ & $0.825 t$ & 0.956 & 0.967 & 0.941 & 0.927 & 0.982 \\
\hline Intercept & $3.449^{\mathrm{a}}$ & $3.608^{\mathrm{ab}}$ & $3.604^{a}$ & $3.614^{\mathrm{a}}$ & $3.903^{\mathrm{bc}}$ & $4.521^{\mathrm{d}}$ & 3.978 \\
\hline Slope & $-0.009^{\mathrm{a}}$ & $-0.008^{a}$ & $-0.008^{\mathrm{a}}$ & $-0.008^{a}$ & $-0.011^{\mathrm{b}}$ & $-0.018^{\mathrm{c}}$ & -0.011 \\
\hline \multicolumn{8}{|l|}{ Sprouts } \\
\hline$n$ & 14 & 19 & 10 & 12 & 17 & 12 & 19 \\
\hline$R^{2}$ & 0.987 & 0.968 & 0.950 & 0.924 & 0.916 & 0.793 & 0.978 \\
\hline Intercept & $3.861^{\mathrm{d}}$ & $3.563^{\mathrm{cd}}$ & $3.862^{\mathrm{d}}$ & $3.225^{\mathrm{a}}$ & $3.279^{\mathrm{ab}}$ & $3.479^{\mathrm{abcd}}$ & 3.519 \\
\hline Slope & $-0.019^{c}$ & $-0.014^{\mathrm{a}}$ & $-0.033^{\mathrm{e}}$ & $-0.020^{\mathrm{cd}}$ & $-0.015^{\mathrm{ab}}$ & $-0.019^{\mathrm{bc}}$ & -0.017 \\
\hline \multicolumn{8}{|l|}{ Pooled } \\
\hline$n$ & 20 & 25 & 33 & 27 & 20 & 19 & 33 \\
\hline$R^{2}$ & 0.956 & 0.893 & 0.962 & 0.969 & 0.939 & 0.936 & 0.984 \\
\hline Intercept & $3.888^{\mathrm{bc}}$ & $3.901^{\mathrm{abcd}}$ & $3.730^{\mathrm{ab}}$ & $3.690^{\mathrm{a}}$ & $4.010^{\mathrm{cd}}$ & $4.586^{\mathrm{e}}$ & 4.074 \\
\hline Slope & $-0.012^{\mathrm{bc}}$ & $-0.010^{\mathrm{ab}}$ & $-0.009^{\mathrm{a}}$ & $-0.009^{\mathrm{a}}$ & $-0.012^{\mathrm{bc}}$ & $-0.018^{\mathrm{d}}$ & -0.012 \\
\hline
\end{tabular}

Notes: Intercept and slope entries sharing the same lowercase superscript letter are not significantly different at $P<0.05 ; n=$ number of age classes in the cumulative distribution. The slopes between the static and cumulative sprout-age frequency distributions did not differ significantly assuming a constant mortality model. The same was observed for the pooled age distributions. Significant differences were, however, observed between the slopes of the seedling distributions for stands 1,5 , and the lake composite age structure. Within each stand, the regression equations for the sprouts and the seedlings cumulative age distributions differed significantly $(P<0.05)$ except for stand 2 (intercept: $P=0.0814, n=43$ ), stand $3 \mathrm{~b}$ (slope: $P=0.7614, n=31$ ) and stand 5 (intercept: $P=0.7630, n=44$ ). Within each stand, the regression equations for the seedlings and the pooled cumulative age distributions did not differ significantly $(P>0.1)$ except for stand 1 (intercept: $P=0.006$; slope: $P=0.0071, n=40$ ) and stand 5 (intercept: $P=0.0710, n=50$ ).

$\dagger$ No logarithmic transformation: $R^{2}=0.958$, Intercept $=1564.180$, Slope $=-7.008$

$\$$ No logarithmic transformation: $R^{2}=0.972$, Intercept $=1332.726$, Slope $=-7.310$.

distribution of seedlings was also best fit by a linear model with no logarithmic transformation of the data, indicating a constant number of individuals from seed origin in each age class (Table 2).

Compared to seedlings, no clear pattern was observed in the cumulative age distributions of the sprouts due to greater variability among stands. The initial recruitment of sprouts in stand $3 \mathrm{~b}$ was not found to be significantly different from that of the other stands. For this stand, however, the age distribution of the sprouts departed more from linearity, as shown by the lower $R^{2}$ (Fig. 4F, Table 2). Stand 2 also exhibits the greatest sprout mortality rate, as indicated by its steep slope (Fig. 4C, Table 2). When both seedlings and sprouts were pooled the cumulative age distribution shows that both the initial recruitment and mortality rates in stand $3 \mathrm{~b}$ were significantly higher than in the other stands. In stand 4 , both were also significantly higher than in stands 2 and $3 \mathrm{a}$. In stand $1, F$. nigra had also a higher mortality rate than in stands 2 and $3 \mathrm{a}$ and a higher initial recruitment than in stand $3 a$.

In stands 2, 3a, and 4, changes in the slope of the cumulative age distribution over time indicate that $F$. nigra seedlings undergo three phases of mortality (Fig. 4). They show a high mortality rate when young, followed by a period of lower and near constant mortality, after which mortality again increases as the trees get older. The same pattern was observed when both sprouts and seedlings were pooled and this was even more apparent when first-year and $<10$-cm-tall seedlings were considered (Fig. 4). In contrast to seedlings, $F$. nigra sprouts have a higher but almost constant mortality rate (Fig. 4).

\section{Ordination analysis at the $100-\mathrm{m}^{2}$ plot level}

Loadings on the first two axes for both unconstrained PCA (principal-component analysis) and constrained RDA (redundancy analysis) ordinations of the 52100 $\mathrm{m}^{2}$ plots (two were taken out of stand $3 \mathrm{~b}$ ) were significantly cross-correlated (Pearson correlation: $r=$ 0.99 and $-0.99, P<0.0001, n=52$ plots $)$. RDA loadings showed that most of the $100-\mathrm{m}^{2}$ plots were strongly clustered according to geomorphological landform (Fig. 6A, B). The first axis primarily separates plots from stands 1 and 5 from those of stand $3 \mathrm{~b}$, whereas the second axis mainly discriminates between plots of stands 2 and $3 \mathrm{a}$. A number of plots from stands 2 , $3 \mathrm{a}$, and 4 also share a position close to those from stands 1 and 5, which are alike (Fig. 6B). This close relationship with landform was further indicated by the environmental-factor scores. Significant factors retained after a forward selection were stand landform $(1,2,3 \mathrm{a}$, and 3b), elevation, and slope (Fig. 6A). 


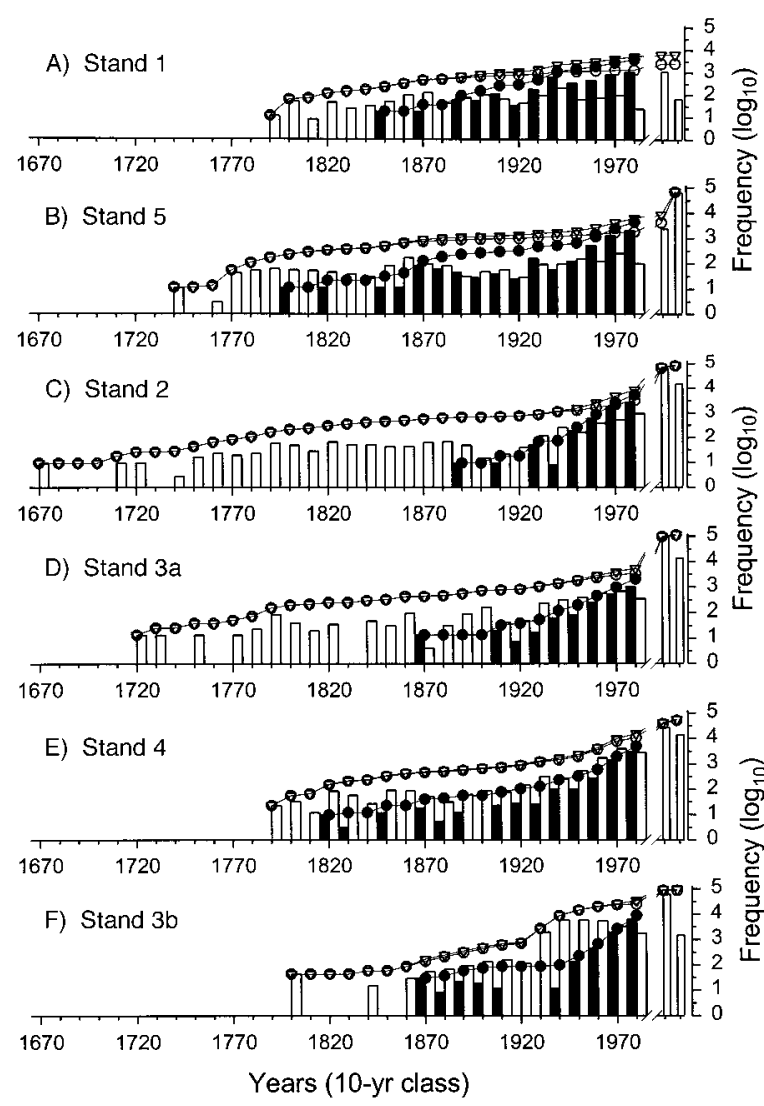

FIG. 4. Fraxinus nigra $\log _{10}$-transformed static and cumulative age distributions for stems from sexual and vegetative origins. The pooled seedling-sprout cumulative age distribution (empty triangles) is also indicated. Filled bars or filled circles $=$ sprouts; empty bars or empty circles $=$ seedlings. Post-break data in each plot include $<10-\mathrm{cm}$ height and first-year seedlings, respectively. Stands are presented in order, top to bottom, of decreasing exposure to flooding.

Loadings of the descriptive measures indicate that, in low-elevation plots from around the lake (primarily stands 1 and 5), both sprout and seedling age distributions were characterized by an older mean age and an older medium age class (Fig. 6A). In these plots, sprouts were also observed in older and distributed among a greater number of age classes. They also present the highest ratio of sprouts over seedlings. In contrast, plots located on a deep organic layer (stand $3 b$ ) and to a lesser extent those of stand 4 , were characterized by strong regeneration in their younger age classes (Fig. 6A, B). In these plots, the high density of young stems from both origins makes their age distributions highly skewed (Fig. 6A). The second ordination axis further divides the $100-\mathrm{m}^{2}$ plots according to elevation and this effect was most noticeable in separating plots from stands 2 and 3 a from the others (Fig. $6 \mathrm{~A}, \mathrm{~B})$. These two stands showed an intermediate position on axis 1 and were characterized by seedlings reaching an older age and being distributed in a greater

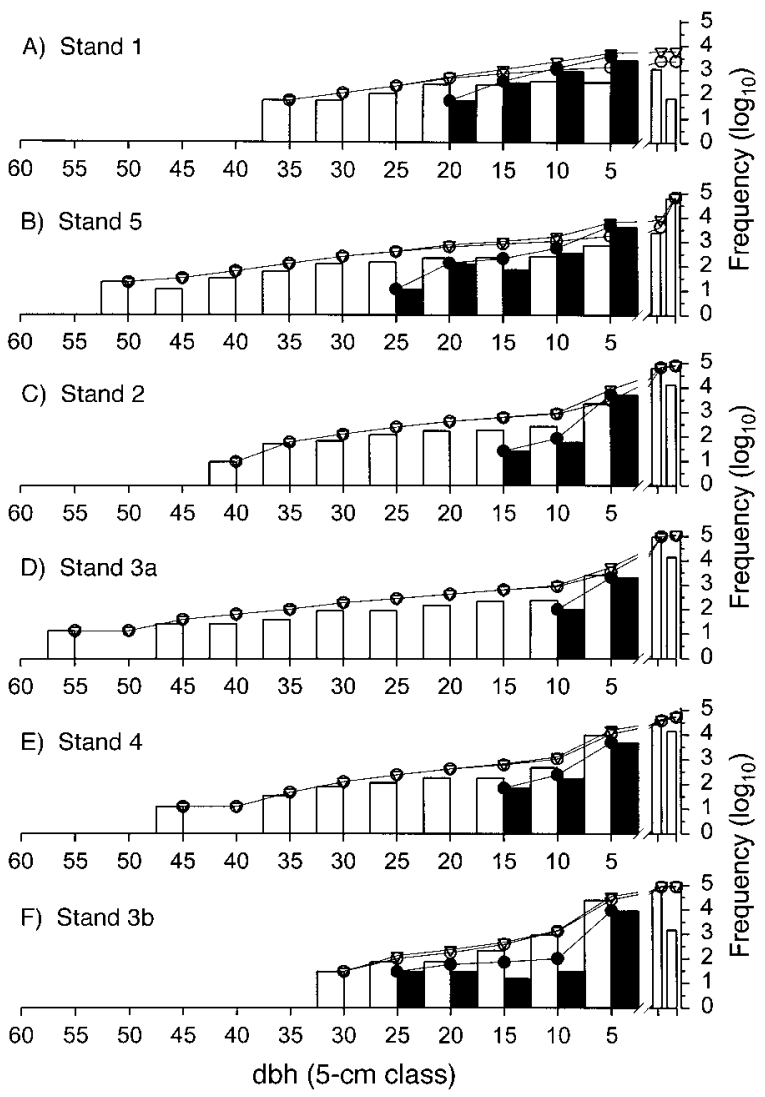

FIG. 5. Fraxinus nigra $\log _{10}$-transformed static and cumulative diameter distributions for stems from sexual and vegetative origins. Format and key are as in Fig. 4.

number of classes. They were also related to the abundance of seedlings $<10 \mathrm{~cm}$ tall (Fig. 6A).

\section{Ordination analysis at the stand and lake level}

The PCA computed for each of the stands and the lake composite age distribution closely matched the pattern of stand division suggested in the RDA. As in the RDA, a recruitment gradient was observed from stand 1 toward stands 2 and $3 \mathrm{~b}$ (Fig. 7). Stands 1 and 5 were characterized by both sprout and seedling age distributions having an older mean age and median age class than the other stands (Fig. 7, Table 3). The ratio of sprouts to seedlings was also highest in these stands. Seedlings $<10 \mathrm{~cm}$ tall were also less abundant than first-year seedlings in stands 1 and 5 (Fig. 7). The seedling distributions in both stands 1 and 5 were also negatively skewed ( -0.81 and -0.33 , respectively) revealing a deficiency in stems from sexual origin in the younger age classes (Table 3 ). In contrast, stand $3 \mathrm{~b}$ and to a lesser extent stand 4 were characterized in their younger age classes by a strong input from both sprouts and seedlings, which results in their age distributions being positively skewed (Fig. 7, Table 3). Compared to these extremes, stands 2, 3a, and the lake composite age distributions were in greater equilibrium. Stems 

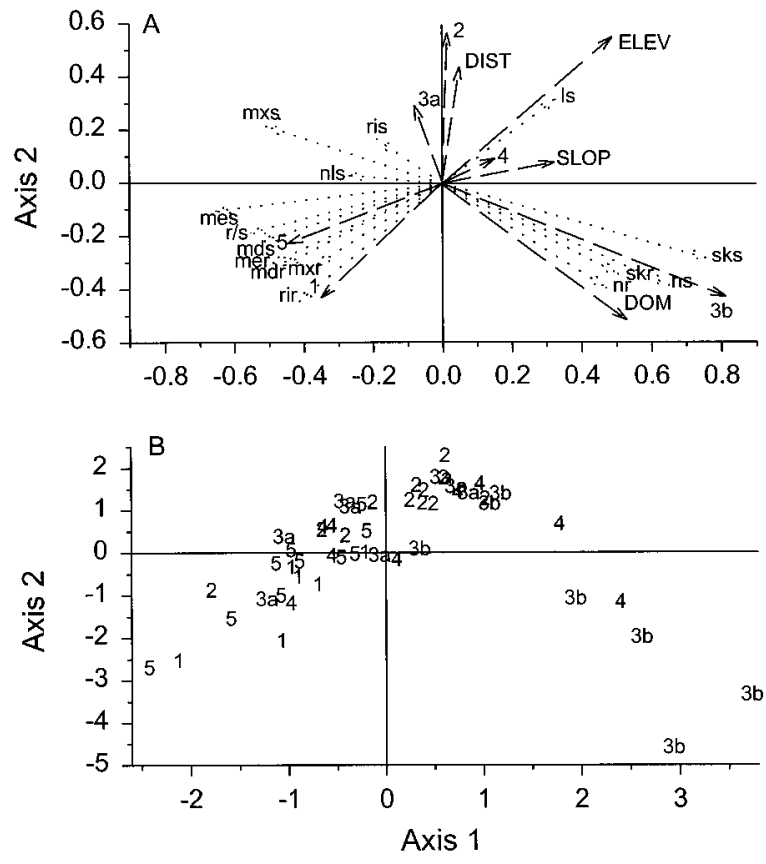

FIG. 6. Redundancy analysis (RDA) using the descriptive measures calculated from each of the $52100-\mathrm{m}^{2}$ plots. (A) The bi-plot yield approximates the correlation coefficient between descriptors and environmental factors and also among descriptors and environmental factors themselves. Variables with arrows at sharp angles are positively correlated, and the length of an arrow represents the size of the coefficient. By contrast, obtuse angles between variables indicate negative correlations. Significant environmental factors retained after a forward selection were stand landform $(1,2,3 a$, and $3 b)$, elevation (ELEV), and slope (SLOP); others factors were made passive in the analysis (DIST $=$ distance, $\mathrm{DOM}=$ depth of organic matter, $4=$ stand 4 , and $5=$ stand 5 ). Dotted lines connect to descriptive age frequency measures whereas dashed lines connect to environmental factors $(\mathrm{nr}=$ abundance of sprouts, mer $=$ mean sprout age, $\mathrm{mdr}=$ median sprout age class, $\mathrm{mxr}=$ maximum sprout age class, $\mathrm{skr}=$ sprout skewness index, rir $=$ number of classes in which sprouts are present, $\mathrm{r} / \mathrm{s}=$ sprout/seedling abundance ratio). First-year seedlings (nls) and those $<10-\mathrm{cm}$ tall (ls) were made passive. (B) The positions along the first two axes of the RDA of all 52 plots from the five stands are shown. from sexual origin were also older and found in a greater number of age classes (Fig. 7, Table 3).

\section{Recruitment, disturbance, and trends in radial growth}

No evidence of large-scale disturbance events related to massive $F$. nigra recruitment was observed in Lake Duparquet stands (Figs. 8-13). In most stands constant recruitment can be observed, whereas in stands $1,3 \mathrm{a}$, and $3 \mathrm{~b}$ it occurred on a more irregular basis (Figs. 8A, $11 \mathrm{~A}, 13 \mathrm{~A})$. Comparing data from all stands, using either the conservative or less conservative method (see Methods, Statistical analysis), few trees have synchronous periods of sharp growth release or suppression (Figs. 8B-13B). More numerous fluctuations in growth were, however, registered in stands 1 and 4 . Following the first recording of a sharp growth fluctuation, each of these stands recorded additional ones, respectively, $16 \%$ and $17 \%$ of the time (Fig. $8 \mathrm{~B}, 12 \mathrm{~B}$ ).

Although there were variations in amplitude, results differ little in terms of the dates when comparing the conservative and less conservative growth release and suppression indices (Figs. 8B-13B). Again, it can be observed that each stand had its own specific pattern of growth release and suppression. Stand 5, for example, had very few fluctuations in growth compared to the other stands (Fig. 9B). Common growth variations between stands were, however, more obvious. A sustained growth release was observed at the beginning of this century in most stands for the 10 -yr period following the $\sim 1896$ peak (Figs. $8 \mathrm{~B}-13 \mathrm{~B}$ ). This growth release was particularly noticeable in stand $3 \mathrm{~b}$ and continued until the early 1930s for many trees. Only in stand 2 was this episode not strongly registered (Fig. 10B). Other growth-release periods can be also observed around the $1825 \mathrm{~s}, 1850 \mathrm{~s}$, and 1930s. Combining data from all stands, a large number of $F$. nigra cores (126/334) also registered a $75 \%$ or more growth suppression in the $10 \mathrm{yr}$ following the 1967 peak (Figs. 8B-13B). This growth suppression period was also less pronounced in stand 1 than in the other stands. These common patterns of growth release and suppression

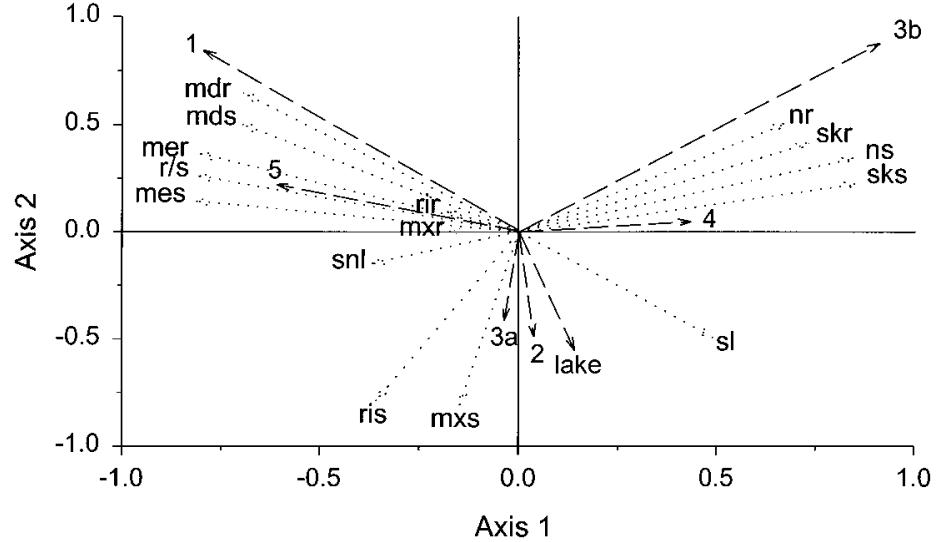

FIG. 7. Principal-component analysis using each of the five stands and the composite lake descriptive measures describing both the static sprout and seedling age distributions. Format and definitions are as in Fig. 6. 
TABLE 3. Descriptive parameters included in the principal-component analysis for each Fraxinus nigra stand. All numbers are for a $100-\mathrm{m}^{2}$ plot.

\begin{tabular}{|c|c|c|c|c|c|c|c|}
\hline \multirow[b]{2}{*}{ Characteristic } & \multicolumn{6}{|c|}{ Stand number } & \multirow{2}{*}{$\begin{array}{c}\text { Entire } \\
\text { lake }\end{array}$} \\
\hline & 1 & 5 & 2 & $3 a$ & 4 & $3 \mathrm{~b}$ & \\
\hline \multicolumn{8}{|l|}{ Seedlings } \\
\hline Abundance & 13.00 & 17.60 & 30.87 & 33.50 & 106.89 & 250.68 & 75.42 \\
\hline Mean age & 86.95 & 92.77 & 54.90 & 56.37 & 30.04 & 38.66 & 42.54 \\
\hline Median age class & 80 & 80 & 30 & 40 & 20 & 40 & 30 \\
\hline Maximum age class & 200 & 250 & 320 & 270 & 200 & 190 & 320 \\
\hline Richness & 20 & 24 & 28 & 24 & 20 & 15 & 29 \\
\hline Skewness & -0.81 & -0.33 & 0.74 & 1.68 & 6.13 & 8.84 & 4.16 \\
\hline \multicolumn{8}{|l|}{ Sprouts } \\
\hline Abundance & 37.61 & 44.37 & 53.20 & 20.38 & 50.20 & 88.70 & 49.07 \\
\hline Mean age & 32.49 & 25.21 & 17.27 & 19.39 & 17.49 & 14.61 & 19.79 \\
\hline Median age class & 30 & 20 & 10 & 10 & 10 & 10 & 10 \\
\hline Maximum age class & 140 & 190 & 100 & 120 & 170 & 120 & 190 \\
\hline Richness & 12 & 16 & 8 & 9 & 14 & 10 & 17 \\
\hline Skewness & 3.48 & 3.53 & 4.44 & 2.51 & 4.70 & 6.83 & 4.15 \\
\hline \multicolumn{8}{|l|}{ Pooled } \\
\hline Abundance & 50.61 & 61.97 & 84.06 & 53.88 & 157.09 & 339.38 & 124.50 \\
\hline Mean age & 46.48 & 44.40 & 31.09 & 42.38 & 26.03 & 32.38 & 33.57 \\
\hline Median age class & 30 & 20 & 20 & 30 & 20 & 30 & 20 \\
\hline Maximum age class & 200 & 250 & 320 & 270 & 200 & 190 & 320 \\
\hline Richness & 20 & 24 & 28 & 24 & 20 & 15 & 29 \\
\hline Skewness & 3.53 & 2.73 & 4.60 & 2.63 & 7.28 & 9.51 & 4.72 \\
\hline Sprout/seedling abundance ratio & 2.89 & 2.52 & 1.72 & 0.61 & 0.47 & 0.35 & 0.65 \\
\hline
\end{tabular}

Note: Richness $=$ the number of age classes with observations.

further emphasize the long-term growth trends (Figs. $8 \mathrm{C}-13 \mathrm{C})$. The growth index curves provide more details about the growth trend in each stand and most of them did register, between the end of the 19th century and the beginning of the 20th century, an upward trend in radial growth that continued to the early 1970s. A pronounced decrease in growth can also be observed in all stands starting in the mid-1960s, with the exception of stand 1, which was located on a sand bar (Fig. 8C).

Only in a few cases can these fluctuations in growth be associated with clear changes in $F$. nigra recruitment. Of the stands most exposed to flooding, only stand 1 had strong recruitment due to sprouts in 1948 (Fig. 8). This event also coincided with a sharp growth release in 1948 , in $10 \%$ of the cores, with an even greater number showing a sustained growth release in the 10 following years (Fig. 8B). This event also coincided with new recruits having better diameter growth (Fig. 8A). In stands 2, 3a, and 4, none of the recruitment episodes corresponded with any of the growth patterns (Figs. 10-12). The massive recruitment that started in the 1930s in stand $3 \mathrm{~b}$ followed a strong growth release that began in the $1900 \mathrm{~s}$, culminated in the 1920s, and lasted to the 1960s (Fig. 13A, B, C).

\section{Discussion \\ Stand stability}

On Lake Duparquet floodplains Fraxinus nigra forms pure stands (Tardif and Bergeron 1992) and composes the "climax" species of this boreal habitat (Sims et al. 1990). Kurmis et al. (1986) also recognized the occurrence of pure uneven-aged stands growing on wet, nutrient-rich sites as a trait of future black ash dominance. Age and size distributions of $F$. nigra from the shore of Lake Duparquet were similar and could typically be described by a skewed distribution with a predominance of small-young stems and progressively fewer large-old trees. This inverted-"J"'-shaped distribution was characteristic of old-growth forests at equilibrium or of self-maintaining "climax" populations (e.g., Oliver and Larson 1990, Hayward 1991). Both even and uneven-aged $F$. nigra populations were also described by Erdmann et al. (1987). In our study, the only even-aged cohort of trees clearly observed was found in stand 3b (see Stand dynamics and flood-level fluctuations, below).

In our study, the negative exponential model, as in Tardif et al. (1994), underestimated the number of stems in the younger age classes, whereas the power function (not presented) overestimated their abundance in the older age classes. A study of the seedling (and pooled) cumulative age distributions also showed that $F$. nigra survivorship changes through time and that during the early phase of establishment stems undergo high levels of mortality. The first $10-50 \mathrm{yr}$ may be crucial, since afterwards the mortality rate decreases and becomes nearly constant from one age class to another. In most stands, a second synchronous period of high mortality was observed when trees become overmature after $\sim 190 \mathrm{yr}$.

The value of static age distributions in studying population dynamics was, however, recently questioned by Johnson et al. (1994) when applied to species known 

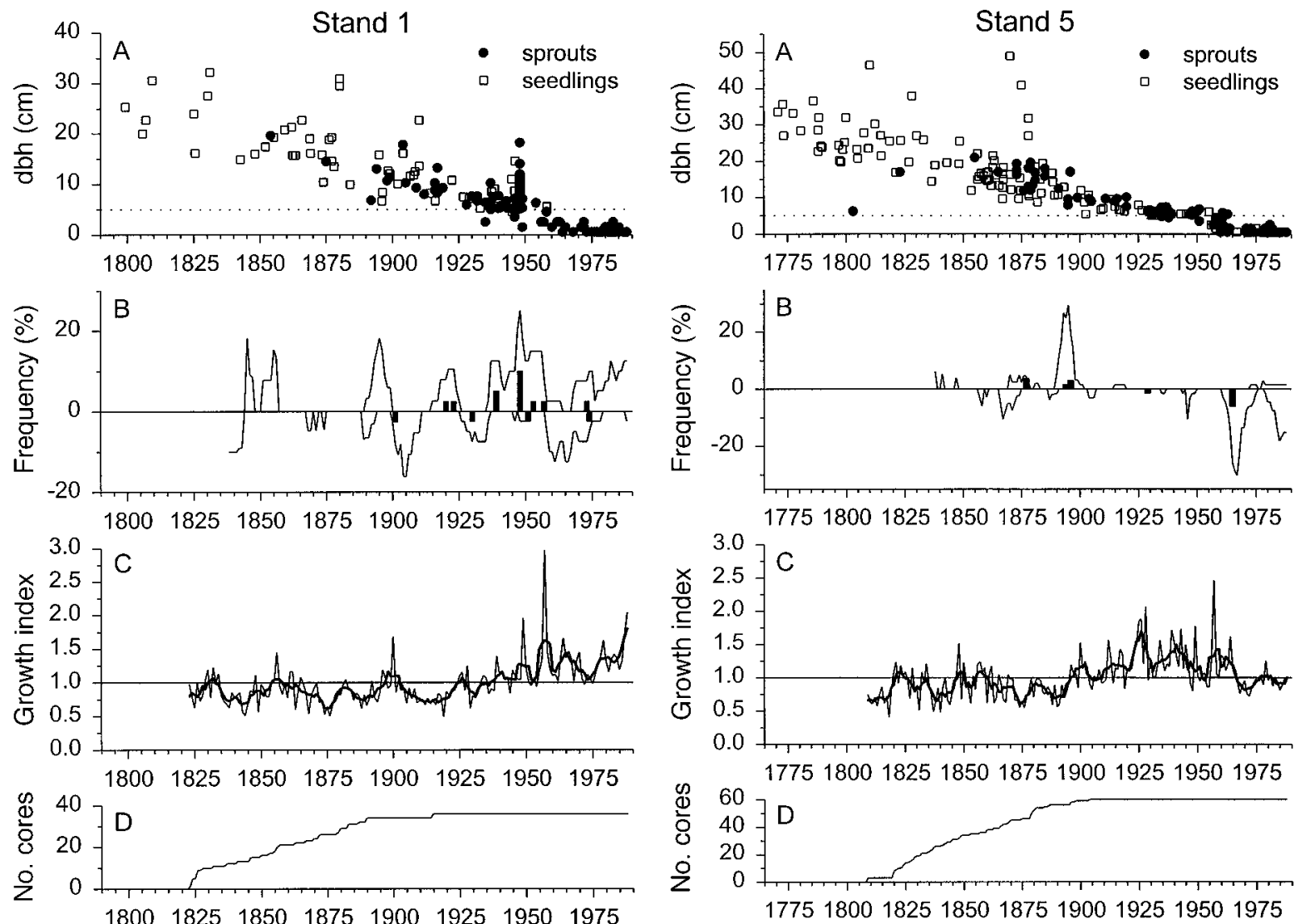

FIG. 9. Relationships between recruitment and radial

FIG. 8. Relationships between recruitment and radial growth in stand 1. (A) Dates of Fraxinus nigra stem establishment. (B) Relative frequency of cores showing a period of growth release (positive value) or suppression (negative value). Filled bars = sharp growth suppression or release; solid line $=$ same but using the less conservative criteria. (C) Radial growth index: solid line $=$ growth index, and bold line $=5$-yr running average. (D) Number of cores.

to regenerate after major disturbances (e.g., fire cohorts vs. non-fire cohorts). It has also been proposed that sigmoidal age and size distributions may reflect a past disturbance followed by a massive wave of recruitment at one point in time (Schmelz and Lindsey 1965, Parker and Peet 1984). This may again be true for species known to regenerate after major disturbances. In such populations, the assumption of stability is not met and this thus precludes the use of the slope of the cumulative age curve as a measure of the probability of survival (Parker and Peet 1984). In our study, however, the uneven-aged nature of the $F$. nigra populations was not an artifact caused by the presence of an even-aged canopy with a developing uneven-aged understory nor by the grouping of many even-aged stands. Our data were also not contaminated by the presence of relic pre-disturbance trees (see Parker and Peet [1984] for discussion).

Inclusion of both younger and smaller stems did not affect the form of the distributions, and we found that the "rotated sigmoid" curve best described $F$. nigra

growth in stand 5. Format is as in Fig. 8.

survival in our closed-canopy forests. These results support those of Goff and West (1975) who observed that size distributions in stable, undisturbed forest populations were better fit by a rotated sigmoid rather than by a negative exponential curve. Stem density in small, equilibrium and structurally uniform old-growth stands decreases abruptly at first, then enters a plateau period of low mortality followed by a final steep decline. Both growth and survivorship are postulated to increase dramatically as trees enter the main canopy (Goff and West 1975). This may also be observed in other "climax" deciduous species. A rotated sigmoid diameter curve was reported by Lorimer and Frelich (1984) for oldgrowth Acer saccharum stands at equilibrium. It was hypothesized that the rotated sigmoid survivorship curve resulted from mortality associated with gapphase regeneration of shade-tolerant tree species (e.g., Harcombe and Marks 1978, West et al. 1981, Platt et al. 1988). Caution must therefore be exercised when assuming that a systematic departure from an exponential distribution reflects non-equilibrium conditions and evidence of past disturbances (Goff and West 1975, Lorimer and Frelich 1984). The theoretical age distribution of a forest at equilibrium - asiderom forming a steep descending curve-istill debated, as are the 

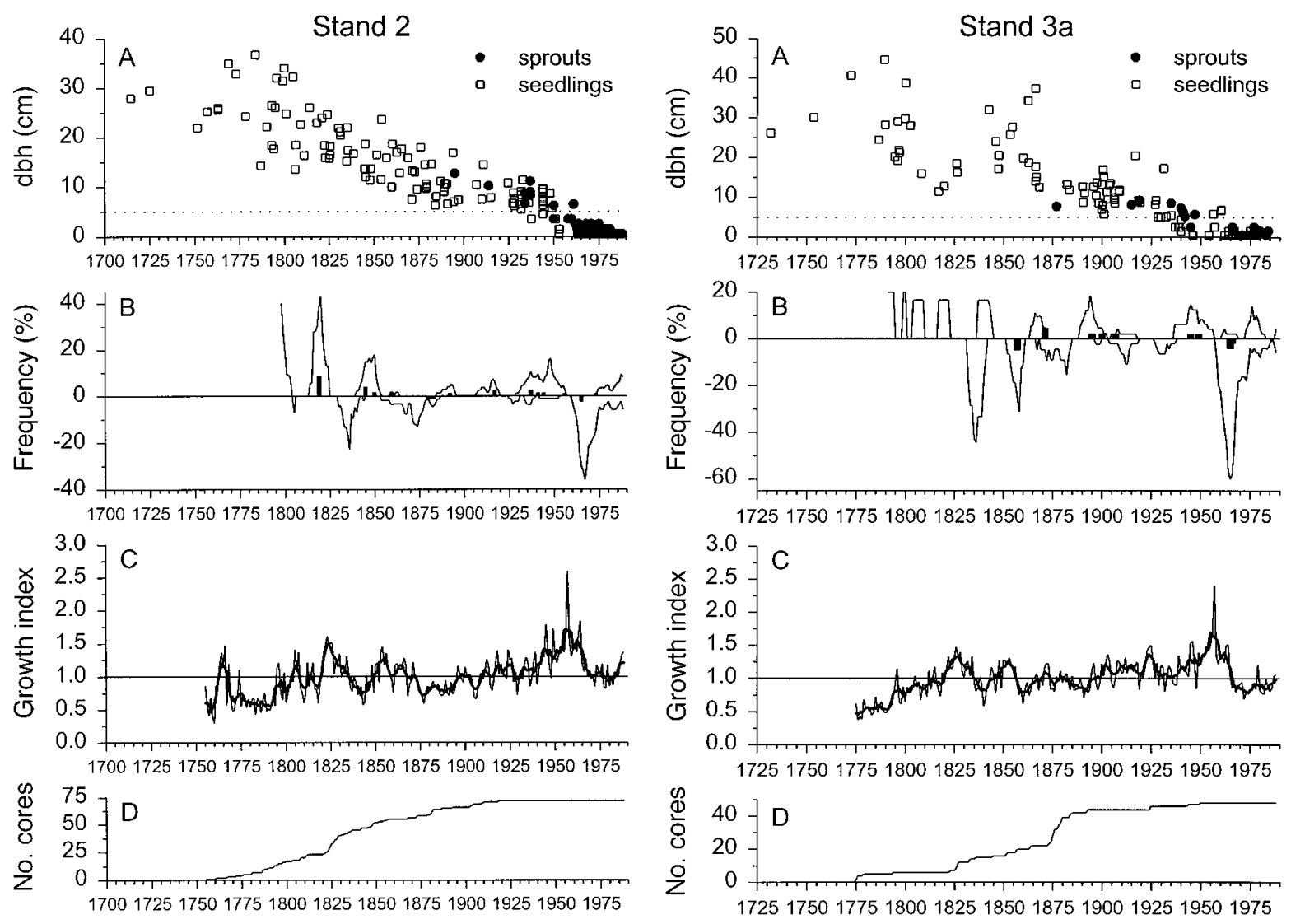

FIG. 11. Relationships between recruitment and radial

FIG. 10. Relationships between recruitment and radial growth in stand 2. Format is as in Fig. 8.

criteria for interpreting deviations related to past disturbances (Lorimer and Frelich 1984).

In contrast to seedlings, the age and size distributions of F. nigra sprouts did not approximate a rotated sigmoid survivorship curve but more closely tracked a negative exponential one. Sprouts also have a higher and more constant mortality rate than seedlings. In our study, however, a bias may have resulted from our inability to identify those older sprouts that no longer bare traces of the mother tree. This may at least partially explain the lower maximum age and size of sprouts when compared to seedlings. The number of sprouts that originated from younger stems was also underestimated. These sprouts, however, do not benefit from a firmly established root system and are expected to have a low survival rate. It was shown by Streng et al. (1989) that survival of water oak's (Quercus nigra) resprouts from first-year seedlings was not significantly different than for first-year seedlings.

Barnes (1985) observed that, among others species, Fraxinus pennsylvanica Marsh. $<10 \mathrm{~cm}$ dbh, once firmly established, has a natural tendency to produce sprouts. Sprouting may also be stimulated by damage caused by flooding or by herbivory. The same tendencies were observed for $F$. nigra, except that browsing was rarely noted. F. nigra is reported to sprout viggrowth in stand 3a. Format is as in Fig. 8.

orously after being damaged (Sims et al. 1990) and to produce root suckers following cutting (Erdmann et al. 1987, Sims et al. 1990). To our knowledge, as was also noted by Fayle (1996) for other tree species, root suckering in $F$. nigra has never been quantified nor are any references with empirical data given in the primary reference. Since $F$. nigra sprouts are more flood and drought tolerant than seedlings (Lees and West 1988, Sims et al. 1990), mortality due to stem competition within a clump is probably very important and may extend over many years. Seldom do many sprouts from the same clump reach the canopy.

We speculate that the great longevity of $F$. nigra trees on the shores of Lake Duparquet may contribute to increased population stability. In the literature, black ash has been frequently described as a short-lived species, with a lifespan of $\sim 75 \mathrm{yr}$ (Lees and West 1988, Sims et al. 1990). Parker and Schneider (1974) reported that the oldest black ash, in their study, was $69 \mathrm{yr}$ old. Our results show, however, that $F$. nigra is a relatively long-lived species. In this study, the oldest living tree established around 1670 (319 yr old) and trees $>200$ yr old were frequent. In the Great Lake states, Erdmann et al. (1987) reported trees as old as 241 yr. On Lake Duparquet floodplains, the old age attained by $F$. nigra trees may be explained by the lack of both major an- 

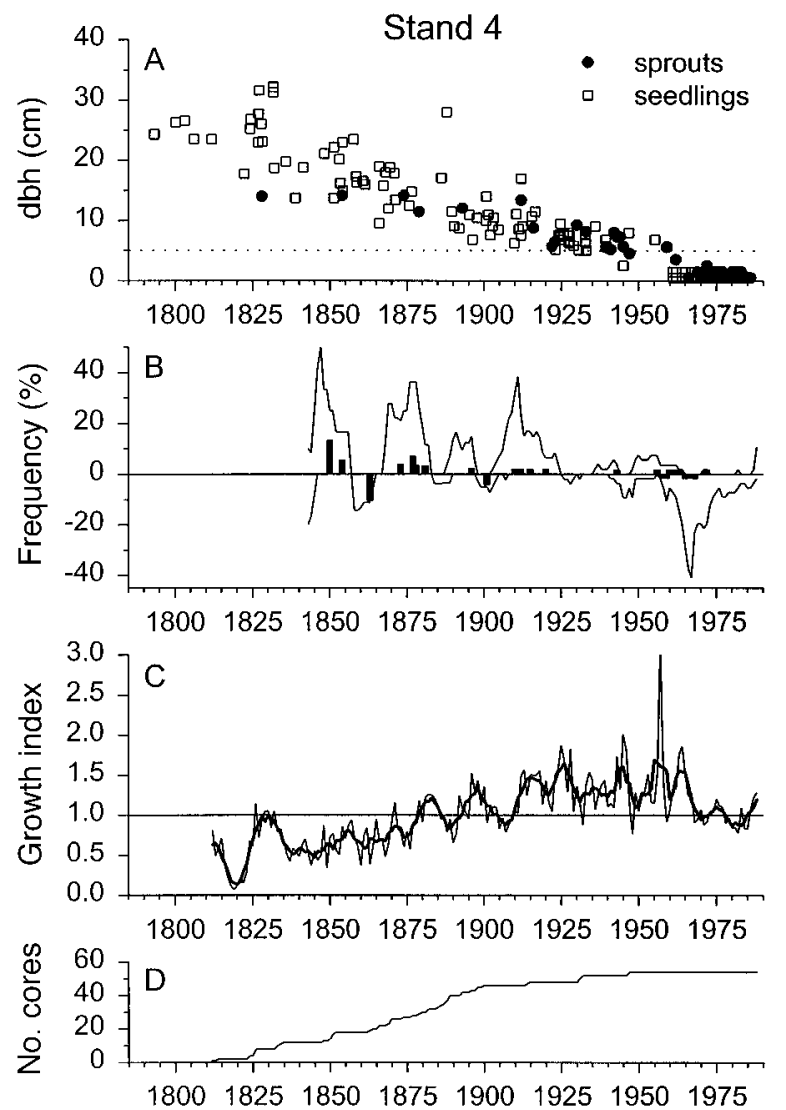

FIG. 12. Relationships between recruitment and radial growth in stand 4. Format is as in Fig. 8.

thropogenic and natural disturbances other than flooding.

\section{Disturbance dynamics}

On Lake Duparquet's shores $F$. nigra recruitment was not associated with large-scale disturbances, as shown by the absence of such records in radial growth patterns. In each stand a few trees registered sharp growth releases but these were rarely synchronized events. In forest stands that develop following destruction of many of the canopy trees, synchronous release from suppression may be expected (Lorimer 1985). In contrast to other boreal stands subject to major disturbances like forest fire, our data support the remark of Carleton and Maycock (1978) that fire does not play a major role in structuring $F$. nigra populations on floodplain sites. In the Lake Duparquet region many mesic sites adjacent to $F$. nigra stands have originated following forest fires (Bergeron 1991, Dansereau and Bergeron 1993). In our study the forest bordering stand 2 developed following a forest fire in 1944 as determinated by dating the largest white birch $(n=12$ birch trees, minimum establishment date $=1949 \pm 5 \mathrm{yr}$ ) as well as by fire scars on $F$. nigra trees on the outer edge of the stand. Only one $100-\mathrm{m}^{2}$ plot recorded a peak in recruitment in the 1940-1949 age class. Furthermore,
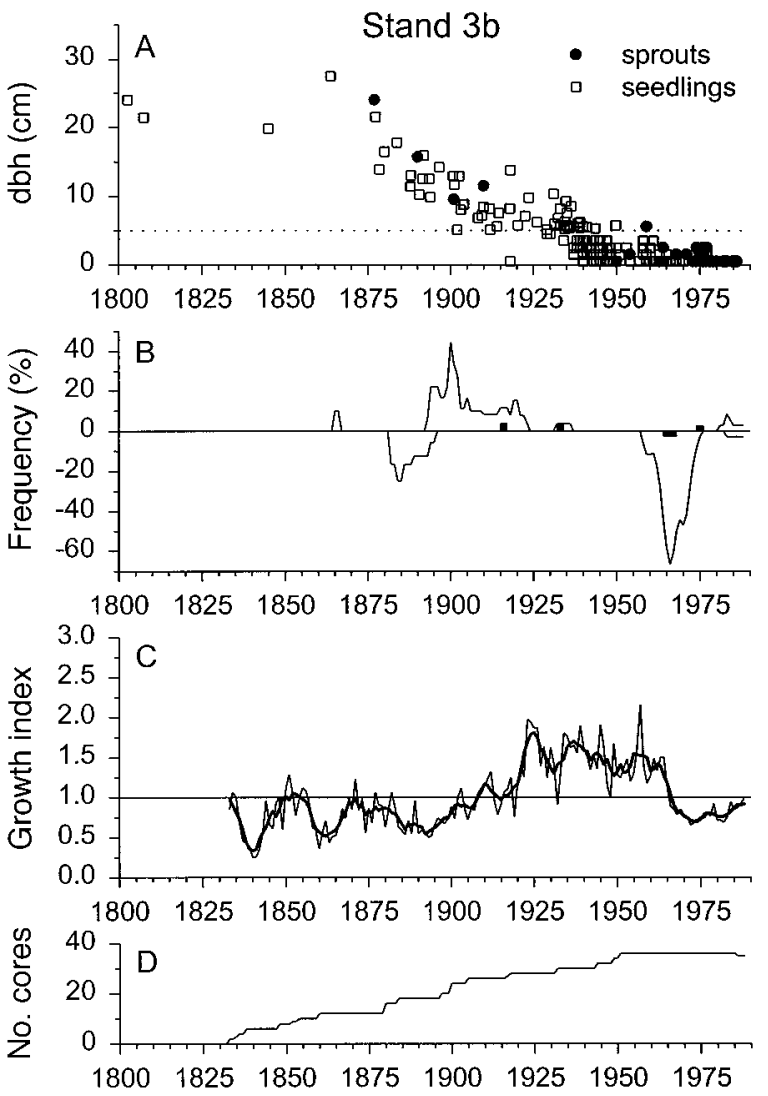

FIG. 13. Relationships between recruitment and radial growth in stand 3 b. Format is as in Fig. 8.

in stand 4 the abundant recruitment that was observed in the plots that were the most elevated and most distant from the lake could also not be related to fire, as shown by the absence of scarred trees and by the old age of the white birch in the bordering forest ( $n=10 \mathrm{birch}$ trees, minimum establishment date $=1857 \pm 37 \mathrm{yr}$ ).

As with northern hardwoods (Payette et al. 1990, Frelich and Lorimer 1991), evidence of tree falls was visible in our stands and it is speculated that most $F$. nigra enter the canopy as a result of these small disturbances - i.e.due to tree by tree replacement. Our data support the rationale that in balanced and unevenaged forests only a small proportion of trees show evidence of sudden release from suppression or rapid initial growth in each decade (Lorimer 1985). Our data also show that in old-growth $F$. nigra stands, sexual or vegetative reproduction is sufficient to result in selfmaintenance of the population following the mortality of mature trees.

Compared to river ecology, landform disturbances (sand bar formation, etc.) were not primary processes influencing $F$. nigra dynamics. On rivers, the creation of new substrates and the destruction of older ones by erosion and deposition processes initiate a particular response from the vegetation (e.g., White 1979). The spatial distribution of stand age for bottomland pioneer 
species like cottonwood and willow was associated with river meandering and formation of new reaches (Noble 1979, Bradley and Smith 1986, Baker 1990, Johnson 1994). These authors emphasized the importance of high-magnitude floods and sediment transportation during the time of seed dispersal on the successful establishment of these species.

On Lake Duparquet's floodplains little clear evidence of geomorphological processes associated with flooding was apparent in those plots that were located within $10 \mathrm{~m}$ of the stand boundaries. Of all the stands only the one found on the sand bar (stand 1) showed a clear synchronous establishment of stems and a sharp growth release in 1948. In this stand, exposed to dominant westerly winds, the conditions created during the high water level of the 1947 flood may have caused many trees to die. Discharge data for the Harricana River ( $100 \mathrm{~km}$ to the west) indicate that for the period 1915 1991 the greatest velocity occurred during the 1947 flood (Tardif and Bergeron 1993). The Abitibi journal La Gazette du Nord also described this flood as being very devastating (Anonymous 1947). In our study, the current shoreline vegetation was not studied, but in our field observations we noted the erosion of the shrub zone in many areas along the shore. At the lake margin many $F$. nigra trees also show direct effects (bark abrasion, branch or stem breakage, stem tilting, and uprooting) of flowing water and drifting ice.

Despite the absence of major disturbance signals in $F$. nigra radial growth, the stand chronologies show a general period of favorable growth beginning in the early 1900 s and lasting to the mid-1960s. We speculate that this widespread period of better growth may be related to improved water relations caused by changes in the regional climate and the lake hydrological regime. Both earlier spring floods (longer growing season) and improved climatic conditions during the growing season may be related to this growth trend (Tardif and Bergeron 1997a). A recent dendrochronological reconstruction of the ice breakup history of Lake Duparquet based on analyses of ice scars further indicates that ice floods are more frequent and reach higher levels in the last $\sim 150 \mathrm{yr}$ than in the preceding period (Tardif and Bergeron 1997b). We speculate that heavier annual precipitation and the occurrence of earlier spring breakups may result in a hydrological regime more conducive to ice damage. Both short- and long- term climatic fluctuations, by their effect on the hydrological regime, may influence $F$. nigra population dynamics.

\section{Stand dynamics and flood-level fluctuations}

Increasing flood water levels during Lake Duparquet's spring ice breakup (Tardif and Bergeron 1997b) may explain the lower establishment of seedlings observed in those stands most exposed to flooding (mainly plots from stands 1 and 5). On these sites, first-year and older seedlings undergo high levels of mortality due probably to flooding and, in particular, to damage caused by moving and standing water. Small seedlings are easily swept away and buried by flood debris ( $\mathrm{Si}$ gafoos 1964, Yanosky 1982). Other factors like drought conditions, deep shade, proximity to a conspecific adult, herbivory, and root competition are also related to first-year and older seedling survival (Lindsey et al. 1961, McBride and Strahan 1984, Streng et al. 1989, Stromberg and Patten 1990, Jones et al. 1994). On the sand bar (stand 1), the ecological conditions created by flooding may also be the most severe, as indicated by the low density of seedlings $<5 \mathrm{~cm} \mathrm{dbh}$. On this site, flood-water velocity and direction may play an additional role in structuring stand dynamics.

On sites exposed to flooding, vegetative reproduction appears to be the primary manner by which new aerial stems are produced. Identification of stump sprouts up to $25 \mathrm{~cm} \mathrm{dbh}$ further demonstrates the importance of sprouts in structuring these populations. Compared to F. nigra seedlings, sprouts have faster height growth and thus more quickly reach a height that allows them to tolerate the effects of flooding. Their vigorous growth can be related to a well-established root system that make them more drought and flood tolerant than single-stem seedlings (Lees and West 1988, Sims et al. 1990). On highly disturbed floodplains, Barnes (1985) observed that sprouting and resprouting contributed more to species propagation than to the number of successful instances of seedlings establishment. On floodplains, vegetative reproduction is an important mechanism by which tree species maintain themselves (Sigafoos 1964, Yanosky 1982, Barnes 1985, Gecy and Wilson 1990, Bégin and Payette 1991, Langlais and Bégin 1993).

On sites exposed to flooding the presence of trees from sexual origin indicates that the ecological conditions needed for their successful establishment are occasionally met. As with Acer saccharinum (Sigafoos 1964), the successful establishment of $F$. nigra seedlings may depend on both favorable weather and edaphic conditions as well as periods without prolonged or intensive flooding until they are firmly established. Our data suggest that these favorable conditions may occur more frequently on sites less exposed to flooding. A shorter flood duration on these sites may allow for a greater number of seedlings to establish successfully. Seedlings of many flood-tolerant floodplain tree species were shown to have higher establishment and survival rates on less frequently flooded sites, i.e., near the highwater mark (Robertson et al. 1978, Barnes 1985, Streng et al. 1989, Jones et al. 1994).

Increasing Lake Duparquet flood levels may also be associated with $F$. nigra establishment and population expansion towards higher elevation sites as new conditions favorable for seedling establishment and survival result. As pointed out by Odgen (1985), skewed size (or age) distributions may arise from stable populations but also from ones migrating into new areas. In both cases, young trees would be numerous and older 
trees scarce. In stand 4, periods with higher flood levels may permit $F$. nigra seeds to germinate and establish only in the higher portion of the stand. Other specific factors such as the death of balsam poplar (Populus balsamifera) may also contribute to black ash establishment. Field observations also suggest that the higher Lake Duparquet shoreline may have been "recently" colonized by black ash trees. When not forming dense stands, $F$. nigra are found scattered along the shoreline in small groups or long strips ranging from one to a few trees. Since $F$. nigra bear long, viable, wind- or water-dispersed seeds (USDA 1948) capable of long periods of dormancy ( $\sim 8 \mathrm{yr}$, Wright and Rauscher 1990), the species may potentially be present in a range of sites waiting for good conditions before breaking seed dormancy followed by germination in the second year.

A temporary or permanent change in flood timing or duration on Lake Duparquet may also be responsible for the recruitment pattern observed in stand $3 \mathrm{~b}$. The clear recruitment pulse observed in the 1930s occurred during a period of increased radial growth. This growth release, clearly observed in older trees and in other stands, is not solely related to the addition of younger trees in this stand chronology. The younger cohorts were mainly observed on plots closest to the shore (data not presented). Climatic events leading to both lower flood levels and drier conditions in some years may have favored $F$. nigra expansion toward the organic portion of this stand. In swamps and sloughs created behind alluvial levees, conditions leading to low flooding and high evaporation may favor species establishment (Hosner and Minckler 1963, Metlzer and Damman 1985). Another hypothesis is that both better growth conditions and $F$. nigra establishment may have resulted from water withdrawal caused by the erosion of the alluvial levee by ice pushes. Data from Tardif and Bergeron (1997b) support the idea that major ice floods on Lake Duparquet were frequent in the 1930 s and 1940s.

\section{Conclusions}

This study shows that at the landscape level the Fraxinus nigra population of Lake Duparquet is well balanced and that mortality appears to be in equilibrium with recruitment. This result does not imply, however, that mortality and recruitment are always constant. Analyses at three scales also show that $F$. nigra populations are in a dynamic equilibrium with the disturbance regime. In our study, major disturbance events did not strongly affect $F$. nigra populations. However, we speculate that annual fluctuations in both duration and timing of flooding were the main factors controlling population dynamics. During successive years of high flood levels seedling establishment may be limited on exposed sites, whereas during dry years sexual recruitment may be limited on higher elevation sites (Tardif et al. 1994). In this study, elevation from the lake (flood duration) was the main ecological factor associated with $F$. nigra regeneration at the $100-\mathrm{m}^{2}$ scale. On more elevated plots, a higher density of young seedlings was observed, whereas on less elevated ones sprouts dominated the younger age classes. Stand geomorphological landform, although related to elevation, was also an important factor in population dynamics. Some $F$. nigra stands relied mainly on vegetative reproduction for self maintenance whereas in others sexual regeneration was more abundant.

On the shore of the Saint Lawrence estuary, Langlais and Bégin (1993) also described similar dynamics for red ash ( $F$. pennsylvanica Marsh.) populations. These authors observed that populations were retreating from the shore tree line in reaction to increasing disturbances by ice activities. In the flood area, the populations were experiencing low sexual recruitment and appeared to maintain themselves by increasing the number of sprouts produced. Away from the shoreline population expansion was due to abundant sexual recruitment.

On Lake Duparquet's floodplains, the persistence of $F$. nigra populations on sites exposed to flooding is believed to be enhanced by the species ability to reproduce vegetatively. This was also illustrated by the smaller difference in the pooled age distribution than in either the individual sprout or seedling age distributions. Both seed dormancy and the ability to sprout indicate that black ash is well adapted to recovery from periodic flooding, and its resilience to change is high in these stands. While sexual reproduction is appropriate for increasing population size over a broad geographical range, vigourous vegetative reproduction promotes immediate and local colonization once successful emergence has occurred (Harper 1977). It also makes a species more likely to survive disturbances (Barnes 1985). According to Holling (1973), unstable communities are often the most resilient because they are likely to contain species well adapted to instability.

If flooding conditions become more severe on Lake Duparquet the resilience of the system may be limited by the availability of new sites for colonization and by the long-term viability of sprouts. At present, F. nigra may benefit from the absence (or elimination) of other shoreline species. In these habitats, however, individuals are scattered and do not create large populations. They are also more exposed to direct damage from floods. The almost complete absence of $F$. nigra stands and specimens on the shore of Lake Abitibi, a nearby lake (15 km north), may reflect the elimination of both the species and its habitat following an approximate rise of $1 \mathrm{~m}$ in the lake's water level in 1915 and its regulation for hydropower production (Lee 1974). Many studies indicate that bottomland tree species including $F$. pennsylvanica do not survive permanent flooding (Green 1947, Hall and Smith 1955, Broadfoot and Williston 1973). We speculate that permanent flooding of the Lake Abitibi floodplain associated with flood control, i.e., a large decrease in both flood am- 
plitude and seasonality, may have caused a dramatic decline in $F$. nigra populations. On Lake Duparquet, both the natural and gradual rise in spring flood levels (Tardif and Bergeron 1997b) have enabled black ash populations to adapt to their changing environment.

\section{ACKNOWLEDGMENTS}

We thank Stéphane Déry and Louis De Grandpré for their help during the field work. We thank Pierre Brisson, Christiane Laroche, Martine Picard, France Conciatori, and MarieClaude Brisson for their assistance during the laboratory tasks. Dr. Jacques Brisson provided a Pascal program to calculate growth release and suppression. We also thank Daniel Kneeshaw for his critical revision of the manuscript and for his help with its translation. We also thank the two anonymous referees for their valuable comments on an earlier version of this manuscript. This study was initiated under a scholarship to J. Tardif and a grant from the Natural Sciences and Engineering Research Council of Canada. This study was also funded by the Ministère de l'Enseignement supérieur et de la science du Québec (Fonds FCAR).

\section{Literature Cited}

Agren, J., and O. Zackrisson. 1990. Age and size structure of Pinus sylvestris populations on mires in central and northern Sweden. Journal of Ecology 78:1049-1062.

Allen, W. T. R. 1964. Break-up and freeze-up dates in Canada. Meteorological Bureau Circular 4116, ICE-17. Transport Canada, Downsview, Ontario, Canada.

Anonymous. 1947. Regards sur la semaine. La Gazette du Nord, 30 May 1947 : page 24 (column 1). Amos, Quebec, Canada.

Apps, M. J., D. T. Price, and J. Wisniewski. 1995. Boreal forests and global change. Water, Air and Soil Pollution. Volume 82. Kluwer Academic Publishers, Boston, Massachusetts, USA.

Baker, W. L. 1990. Climatic and hydrologic effects on the regeneration of Populus angustifolia James along the Animas River, Colorado. Journal of Biogeography 17:59-73

Barnes, W. J. 1985. Population dynamics of woody plants on a river island. Canadian Journal of Botany 63:647-655.

Bégin, Y., and S. Payette. 1991. Population structure of lakeshore willows and ice-push events in subarctic Québec, Canada. Holarctic Ecology 14:9-17.

Bergeron, Y. 1991. The influence of island and mainland lakeshore landscape on boreal forest fire regimes. Ecology 72:1980-1992.

Bergeron, Y., and S. Archambault. 1993. Decreasing frequency of forest fires in the southern boreal zone of Québec and its relation to global warming since the end of the "Little Ice Age." Holocene 3:255-259.

Bergeron, Y., and A. Bouchard. 1984. Use of ecological groups in analysis and classification of plants communities in a section of western Québec. Vegetatio 56:45-63.

Bergeron, Y., A. Bouchard, P. Gangloff, and C. Camiré. 1983. La classification écologique des milieux forestiers de la partie ouest des cantons d'Hébécourt et de Roquemaure, Abitibi, Québec. Études écologiques 9. Laval University, Sainte-Foy, Quebec, Canada.

Bergeron, Y., and M. D. Flannigan. 1995. Predicting the effects of climate change on fire frequency in the southeastern Canadian forest. Water, Air and Soil Pollution 82: 437-444.

Bergeron, Y., and D. Gagnon. 1987. Age structure of red pine (Pinus resinosa Ait.) at its northern limit in Québec. Canadian Journal of Forest Research 17:129-137.

Bradley, C. E., and D. G. Smith. 1986. Plains cottonwood recruitment and survival on a prairie meandering river floodplain, Milk River, southern Alberta and northern Montana. Canadian Journal of Botany 64:1433-1442.
Bradley, R. S., H. F. Diaz, J. K. Eischeid, P. D. Jones, P. M. Kelly, and C. M. Goodess. 1987. Precipitation fluctuations over Northern Hemisphere land areas since the mid-19th century. Science 237:171-175.

Broadfoot, W. M., and H. L. Williston. 1973. Flooding effects on southern forests. Journal of Forestry 71:584-587.

Butson, R. G., P. Knowles, and R. E. Farmer, Jr. 1987. Age and size structure of marginal disjunct populations of Pinus resinosa. Journal of Ecology 75:685-692.

Carleton, T. J., and P. F. Maycock. 1978. Dynamics of the boreal forest south of James Bay. Canadian Journal of Botany 56:1157-1173.

Cawker, K. B. 1980. Evidence of climatic control from population age structure of Artemisia tridentata Nutt. in southern British Columbia. Journal of Biogeography 7:237-248.

Clark, J. S. 1988. Effect of climate change on fire regimes in northwestern Minnesota. Nature 334:233-235.

Dansereau, P. R., and Y. Bergeron. 1993. Fire history in the southern boreal forest of northwestern Québec. Canadian Journal of Forest Research 23:25-32.

DuBarry, A. P., Jr. 1963. Germination of bottomland tree seed while immersed in water. Journal of Forestry 61:225226.

Environment Canada. 1993. Canadian climate normals. Canadian climate program. Environment Canada. Atmospheric Environment Service, Downsview, Ontario, Canada.

Erdmann, G. G., T. R. Crow, R. M. Peterson, and C. D. Wilson. 1987. Managing black ash in the Lake states. USDA Forest Service General Technical Report NC-115.

Fayle, C. F. D. 1996. Sugar maple, black spruce and tamarack do not reproduce vegetatively from roots. Forestry Chronicle 72:281-285.

Folland, C. K., T. R. Karl, and K. Ya. Vinnikov. 1990. Observed climate variations and change. Pages 195-238 in J. T. Houghton, G. J. Jenkins, and J. J. Ephraums, editors. Climate changes, the IPCC scientific assessment. Cambridge University Press, Cambridge, UK.

Frelich, L. E., and C. G. Lorimer. 1991. Natural disturbance regimes in the hemlock-hardwood forest of the upper Great Lakes region. Ecological Monographs 61:145-164.

Fritts, H. C. 1976. Tree rings and climate. Academic Press, New York, New York, USA.

Gecy, J. L., and M. V. Wilson. 1990. Initial establishment of riparian vegetation after disturbance by debris flows in Oregon. American Midland Naturalist 123:282-291.

Glitzenstein, J. F., P. A. Harcombe, and D. R. Streng. 1986. Disturbance, succession, and maintenance of species diversity in an east Texas forest. Ecological Monographs 46: $243-258$.

Goff, F. G., and D. West. 1975. Canopy-understory interaction effects on forest population structure. Forest Science 21:98-108.

Green, W. E. 1947. Effect of water impoundment on tree mortality and growth. Journal of Forestry 45:188-120.

Hall, T. F., and G. E. Smith. 1955. Effects of flooding on woody plants. West Sandy Dewatering Project, Kentucky Reservoir. Journal of Forestry 53:281-285.

Harcombe, P. A., and P. L. Marks. 1978. Tree diameter distributions and replacement processes in southeast Texas forest. Forest Science 24:153-166.

Harper, J. L. 1977. Population biology of plants. Academic Press, London, UK.

Harvey, B. D., and Y. Bergeron. 1989. Site patterns of natural regeneration following clear-cutting in northwestern Québec. Canadian Journal of Forest Research 19:1458-1469.

Hayward, G. D. 1991. Using population biology to define old-growth forests. Wildlife Society Bulletin 19:111-116.

Henry, J. D., and J. M. A. Swan. 1974. Reconstructing forest history from live and dead plant material-an approach to 
the study of forest succession in southwest New Hampshire. Ecology 55:772-783.

Hett, J. M. 1971. A dynamic analysis of age in sugar maple seedlings. Ecology 52:1071-1074.

Hett, J. M., and O. L. Loucks. 1976. Age structure models of balsam fir and eastern hemlock. Journal of Ecology 64: 1029-1044.

Holling, C. S. 1973. Resilience and stability of ecological systems. Annual Review of Ecology and Systematics 4:123.

Holmes, R. L. 1992. Dendrochronology program library, version 1992-1. Laboratory of Tree-Ring Research, University of Arizona, Tucson, Arizona, USA.

Hosner, J. F. 1957. Effects of water upon the seed germination of bottomland trees. Forest Science 3:67-70.

Hosner, J. F., and S. G. Boyce. 1962. Tolerance to watersaturated soil of various bottomland hardwoods. Forest Science 8:180-186.

Hosner, J. F., and L. S. Minckler. 1963. Bottomland hardwood forest of southern Illinois - regenerationnd succession. Ecology 44:29-41.

Johnson, E. A., K. Miyanishi, and H. Kleb. 1994. The hazards of interpretation of static age structures as shown by stand reconstruction in a Pinus contorta-Picea engelmannii forest. Journal of Ecology 82:923-931.

Johnson, W. C. 1994. Woodland expansion in the Platte River, Nebraska: pattern and causes. Ecological Monographs 64:45-84.

Jones, P. D., and K. R. Briffa. 1992. Global surface air temperature variations during the twentieth century. Part 1 Spatial, temporal and seasonal details. Holocene 2:165179.

Jones, R. H., R. R. Sharitz, P. M. Dixon, D. S. Segal, and R. L. Schneider. 1994. Woody plant regeneration in four floodplain forests. Ecological Monographs 64:345-367.

Karl, T. R., P. Y. Groisman, R. W. Knight, and R. R. Heim Jr. 1993. Recent variations of snow cover and snowfall in North America and their relationship to precipitation and temperature variations. Journal of Climate 6:1327-1344.

Knowles, P., and M. C. Grant. 1983. Age and size structure analyses of Engelman spruce, ponderosa pine, lodgepole pine, and limber pine in Colorado. Ecology 64:1-9.

Kurmis, V., S. L. Webb, and L. C. Merriam, Jr. 1986. Plant communities of Voyageurs National Park, Minnesota, U.S.A. Canadian Journal of Botany 64:531-540.

Lamb, H. H. 1982. Climate, history and the modern world. Methuen, New York, New York, USA.

Langlais, D., and Y. Bégin. 1993. The effects of recent floods and geomorphic processes on red ash populations, upper St. Lawrence estuary, Québec. Estuarine, Coastal and Shelf Science 37:525-538.

Leak, W. B. 1975. Age distribution in virgin red spruce and northern hardwoods. Ecology 56:1451-1454.

Lee, T. E. 1974. The Fort Abitibi mystery. Collection PaléoQuébec, Centre d'études nordiques, Laval University, Sainte-Foy, Québec, Canada.

Lees, J. C., and R. C. West. 1988. A strategy for growing black ash in the maritimes provinces. Technical Note number 201. Canadian Forestry Service-Maritimes, Fredericton, New Brunswick, Canada.

Legendre, L., and P. Legendre. 1984. Ecologie numérique. 2. La structure des données écologiques. Collection d'écologie 13. Masson, Paris, France.

Lindsey, A. A., R. O. Petty, D. K. Sterling, and W. VanAsdall. 1961. Vegetation and environment along the Wabash and Tippecanoe rivers. Ecological Monographs 31:105-156.

Lorimer, C. G. 1980. Age structure and disturbance history of a southern Appalachian virgin forest. Ecology 61:11691184.

1985. Methodological considerations in the analysis of forest disturbance history. Canadian Journal of Forest Research 15:200-213.

Lorimer, C. G., and L. E. Frelich. 1984. A simulation of equilibrium diameter distributions of sugar maple (Acer saccharum). Bulletin of the Torrey Botanical Club 111: 193-199.

McBride, J. R., and J. Strahan. 1984. Establishment and survival of woody riparian species on gravel bars of an intermittent stream. American Midland Naturalist 112:235245.

Metzler, K. J., and W. H. Damman. 1985. Vegetation patterns in the Connecticut river flood plain in relation to frequency and duration of flooding. Naturaliste Cananadien 112:535547.

Noble, M. G. 1979. The origin of Populus deltoides and Salix interior zones on point bars along the Minnesota River. American Midland Naturalist 102:59-67.

Odgen, J. 1985. An introduction to plant demography with special reference to New Zealand trees. New Zealand Journal of Botany 23:751-772.

Oliver, C. D., and B. C. Larson. 1990. Forest stand dynamics. McGraw-Hill, New York, New York, USA.

Orwig, D. A., and M. D. Abrams. 1994. Contrasting radial growth and canopy recruitment patterns in Liriodendron tulipifera and Nissa sylvatica: gap-obligate versus gap-facultative tree species. Canadian Journal of Forest Research 24:2141-2149.

Overpeck, T., D. Rind, and R. Goldberg. 1990. Climateinduced changes in forest disturbance and vegetation. Nature 343:51-53

Palik, B. J., and K. S. Pregitzer. 1992. The age and height structure of red maple (Acer rubrum) populations in northern Michigan bigtooth aspen (Populus grandidentata) forests. Canadian Journal of Forest Research 22:1449-1462.

Parker, A. J., and R. K. Peet. 1984. Size and age structure of conifer forest. Ecology 65:1685-1689.

Parker, G. R., and G. Schneider. 1974. Structure and edaphic factors of an alder swamp in northern Michigan. Canadian Journal of Forest Research 4:499-508.

Payette, S., L. Fillion, and A. Delwaide. 1990. Disturbance regime of a cold temperate forest as deduced from treering patterns: the Tantare Ecological Reserve, Québec. Canadian Journal of Forest Research 20:1228-1241.

Phipps, R. L. 1970. The potential use of tree rings in hydrologic investigations in eastern North America with some botanical considerations. Water Resources Research 6: 1634-1640.

Pickett, S. T. A. 1980. Non-equilibrium coexistence of plants. Bulletin of the Torrey Botanical Club 107:238-248.

Pickett, S. T. A., and P. S. White. 1985. The ecology of natural disturbance and patch dynamics. Academic Press, Boston, Massachusetts, USA.

Platt, W. J., G. W. Evans, and S. L. Rathbun. 1988. The population dynamics of a long-lived conifer (Pinus palustris). American Naturalist 131:491-525.

Robertson, P. A., G. T. Weaver, and J. A. Cavanaugh. 1978. Vegetation and tree species patterns near the northern terminus of the southern floodplain forest. Ecological Monographs 48:249-267.

Ross, M. S., T. L. Sharik, and D. Wm. Smith. 1982. Agestructure relationships of tree species in an Appalachian oak forest in southwest Virginia. Bulletin of the Torrey Botanical Club 109:287-298.

Rowe, J. S. 1972. Les régions forestières du Canada. Information Canada, Publication Number 1300F. Ministry of Environment, Canadian Forest Service, Ottawa, Ontario, Canada.

SAS Institute 1988. SAS/STAT user's guide, release 6.03 edition. SAS Institute, Cary, North Carolina, USA.

Schmelz, D. V., and A. A. Lindsey. 1965. Size-class structure 
of old-growth forest in Indiana. Forest Science 11:258264.

Sigafoos, R. S. 1964. Botanical evidence of floods and floodplain deposition. U.S. Geological Survey Professional Paper 485-A. U.S. Government Printing Office, Washington, D.C., USA.

Sims, R. A., H. M. Kershaw, and G. M. Wickware. 1990. The autecology of major tree species in the north central region of Ontario. Ontario Ministry of Natural Resources Publication $\mathbf{5 3 1 0 .}$

Stokes, M. A., and T. L. Smiley. 1968. An introduction to tree-ring dating. University of Chicago Press, Chicago, Illinois, USA.

Streng, D. A., J. S. Glitzenstein, and P. A. Harcombe. 1989. Woody seedling dynamics in an east Texas floodplain forest. Ecological Monographs 59:177-204.

Stromberg, J. C., and D. T. Patten. 1990. Seed production and seedling establishment of a southwest riparian tree, Arizona walnut (Juglans major). Great Basin Naturalist 50: 47-56.

Tardif, J. 1996. Earlywood, latewood and total ring width of a ring-porous species (Fraxinus nigra Marsh.) and its relationship with climatic and hydrologic factors. Pages 315 325 in S. D. Dean, D. M. Meko, and T. W. Swetnam, editors Tree rings, environment, and humanity: proceedings of the international conference (Tucson, Arizona, USA; 17-21 May 1994). Radiocarbon, Department of Geosciences, University of Arizona, Tucson, Arizona, USA.

Tardif, J., and Y. Bergeron. 1992. Analyse écologique des peuplements de frêne noir (Fraxinus nigra Marsh.) des rives du Lac Duparquet, nord-ouest du Québec. Canadian Journal of Botany 70:2294-2302.

Tardif, J., and Y. Bergeron. 1993. Radial growth of Fraxinus nigra in a Canadian boreal floodplain in response to climatic and hydrological fluctuations. Journal of Vegetation Science 4:751-758.

Tardif, J., and Y. Bergeron. 1997a. Comparative dendroclimatological analysis of two black ash and two white cedar populations from contrasting sites in the Lake Duparquet region, northwestern Québec. Canadian Journal of Forest Research 27:108-116.
Tardif, J., and Y. Bergeron. 1997b. Ice-flood reconstructed from tree rings at the southern boreal forest limit, western Québec. Holocene 7:291-300.

Tardif, J., S. Déry, and Y. Bergeron. 1994. Sexual regeneration of black ash (Fraxinus nigra) in a boreal floodplain. American Midland Naturalist 132:124-135.

ter Braak, C. J. F. 1988. Canoco-GORTRAN program for canonical community ordination by [partial] [detrended] [canonical] correspondence analysis, principal components analysis and redundancy analysis (version 2.1). Agriculture Mathematics Group, Wageningen, The Netherlands.

Tyrell, L. E., and T. R. Crow. 1994. Structural characteristics of old-growth hemlock-hardwood forests in relation to age. Ecology 75:370-386.

USDA [U.S. Department of Agriculture]. 1948. Fraxinus. Pages 178-183 in Woody-plant seed manual. Miscellaneous Publication 654. United States Department of Agriculture, Forest Service, Washington, D.C., USA.

Veillette, J. J. 1994. Evolution and paleohydrology of glacial lakes Barlow and Ojibway. Quaternary Science Review 13: 945-971.

West, D. C., H. H. Shugart, Jr., and J. W. Ramney. 1981. Population structure of forest over a large area. Forest Science 227:701-710

White, P. S. 1979. Pattern, process and natural disturbance in vegetation. Botanical Review 45:229-299.

1987. Natural disturbance, patch dynamics, and landscape pattern in natural areas. Natural Areas Journal 7:14-22.

Wright, J. W., and H. M. Rauscher. 1990. Black ash. Pages 344-347 in R. M. Burns and B. H. Honkala, editors, Silvics of North America. Volume 2, Hardwoods. Agricultural Handbook 654. United States Department of Agriculture, Washington, D.C., USA.

Yanosky, T. M. 1982. Effects of flooding upon woody vegetation along parts of the Potomac River flood plain. United States Geological Survey Professional Paper Number 1206. Zavel'skaya, N. A., N. V. Zukert, E. Yu. Polyakova, and A. A. Pryazhnikov. 1993. Prediction of the effect of climate changes on boreal areas of Russia. Lesovedenie 1:16-24. 